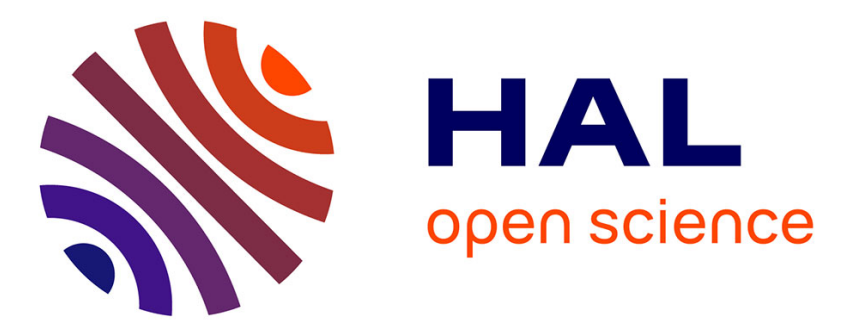

\title{
Aza-aromatic polycycles based on triphenylene and acridine or acridone: synthesis and properties
}

Salima Bouarfa, Philippe Jéhan, William Erb, Olivier Mongin, François-Hugues Porée, Thierry Roisnel, Ghenia Bentabed-Ababsa, Nicolas Le Yondre, Florence Mongin

\section{To cite this version:}

Salima Bouarfa, Philippe Jéhan, William Erb, Olivier Mongin, François-Hugues Porée, et al.. Azaaromatic polycycles based on triphenylene and acridine or acridone: synthesis and properties. New Journal of Chemistry, 2021, 45 (32), pp.14414-14424. 10.1039/D1NJ02630E . hal-03302148

HAL Id: hal-03302148

https://hal-univ-rennes1.archives-ouvertes.fr/hal-03302148

Submitted on 21 Sep 2021

HAL is a multi-disciplinary open access archive for the deposit and dissemination of scientific research documents, whether they are published or not. The documents may come from teaching and research institutions in France or abroad, or from public or private research centers.
L'archive ouverte pluridisciplinaire HAL, est destinée au dépôt et à la diffusion de documents scientifiques de niveau recherche, publiés ou non, émanant des établissements d'enseignement et de recherche français ou étrangers, des laboratoires publics ou privés. 


\title{
Aza-aromatic polycycles based on triphenylene and acridine or acridone: synthesis and properties
}

\author{
Salima Bouarfa, a,b Philippe Jéhan, ${ }^{c}$ William Erb, ${ }^{a}$ Olivier Mongin, ${ }^{a}$ François-Hugues Porée, ${ }^{a}$ \\ Thierry Roisnel, ${ }^{a}$ Ghenia Bentabed-Ababsa, ${ }^{\mathrm{b}}$ Nicolas Le Yondre*c and Florence Mongin*c

\begin{abstract}
Acridine- and acridone-based polycyclic aromatics were prepared by using as the key steps a copper-catalysed $\mathrm{N}$-arylation of 2-aminobenzaldehyde, 2-aminophenones, or ethyl 2-aminobenzoate with 2-iodotriphenylene, and an acid-mediated cyclization. The regioselectivity of this intramolecular $\mathrm{S}_{\mathrm{E}} \mathrm{Ar}$ reaction was studied by performing Hückel theory calculations on the precursors. Due to their structural similarity with some MALDI-MS matrices, two acridine-based polycycles were evaluated for this purpose. Finally, in view of structure-properties relationships, preliminary studies of the photophysical properties of the synthesized acridine- and acridone-based polycycles were performed.
\end{abstract}

\section{Introduction}

Acridines and acridones are planar skeletons that play an important role in biologically active molecules, but also in organic materials for various applications. ${ }^{1-3}$ For example, both acridine and acridone patterns have been found in fluorescent sensors 4,5 and in hole transporting materials.6,7

Polyaromatic hydrocarbons (PAHs) are also structural units playing an important role in compounds endowed with biological and physicochemical (e.g. electronic and photophysical) properties. ${ }^{8}$ Furthermore, the incorporation of one or more nitrogen atoms into PAHs has attracted the attention of chemists due to the impact of this heteroatom on the properties of these organic scaffolds. ${ }^{9-12}$ However, the development of materials based on nitrogencontaining PAHs depends on the availability of synthetic methods that can be used to access them. For example, few studies have been dedicated to the synthesis of acridine- and acridone-based PAHs with more than five rings. ${ }^{13}$

In pioneered studies, Buu-Hoï and co-workers obtained benzo[c]and benzo[a]naphth[2,1-j]acridines from $\alpha$ - and $\beta$-naphthol, respectively, by regioselective Ullmann-Fetvadjian reaction with 2 aminophenanthrene in the presence of paraformaldehyde (Figure 1, top). ${ }^{14}$ Similarly, benzo $[c]$ - and benzo[ $\left.a\right]$ naphth $[2,3-h]$ acridines were

a. Univ Rennes, CNRS, ISCR (Institut des Sciences Chimiques de Rennes) - UMR 6226, F-35000 Rennes, France. E-mail: florence.mongin@univ-rennes1.fr

b. Laboratoire de Synthèse Organique Appliquée, Faculté des Sciences Exactes et Appliquées, Université d'Oran 1 Ahmed Ben Bella, BP 1524 El M'Naouer, 31000 Oran, Algeria. E-mail: bentabedg@gmail.com

c. Univ Rennes, CNRS, ScanMat - UMS 2001, Centre Régional de Mesures Physiques de l'Ouest - CRMPO, F-35000, Rennes, France. E-mail: nicolas.leyondre@univrennes1.fr

+ Electronic Supplementary Information (ESI) available: General information and crystallographic details; Experimental procedures and analyses of intermediate compounds; NMR spectra of the new compounds as well as numbering used in the experimental section; Highest occupied Hückel molecular orbitals (HOMO); Qualitative evaluation of two polycycles as matrices for MALDI-MS. CCDC 2085922 , 2085923. For ESI and crystallographic data in CIF, see DOI: 10.1039/x0xx00000x respectively prepared from $\alpha$ - and $\beta$-naphthol by reaction with 1 aminoanthracene while using 2-aminoanthracene furnished benzo[c]- and benzo[a]naphth[2,3-j]acridines, respectively (Figure 1, middle and bottom). ${ }^{15}$

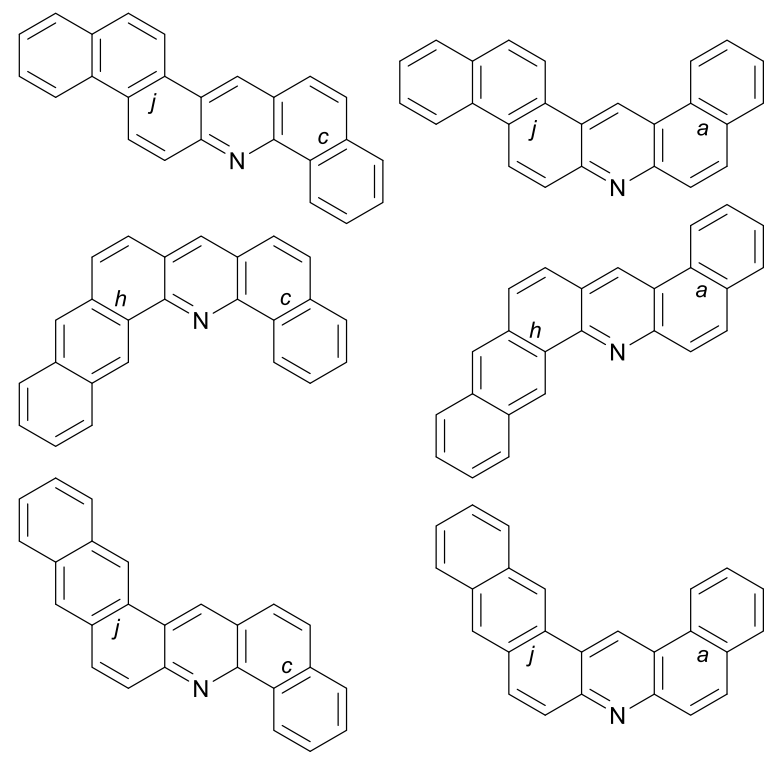

Figure 1 Benzo[c]- and benzo[a]naphth[2,1-j]acridines, benzo[c]- and benzo[ $a]$ naphth $[2,3-h]$ acridines, and benzo[c]- and benzo[ $a]$ naphth $[2,3-$ j]acridines already prepared..$^{14,15}$

As evidenced by recent studies, accessing acridine-based PAHs is always a challenge. For example, Hashmi and co-workers reported in 2018 a $\pi$-extending strategy towards dibenzo[a,c]acridines using gold-catalysis for $\mathrm{C}-\mathrm{H}$ annulation of 2-ethynylbiaryls with anthranils. ${ }^{16}$ We can also cite the modified iron-catalysed Povarov reaction involving 2-(2'-alkynylaryl)benzaldehydes and arylamines documented by Jana and co-workers in 2020 to access the same scaffolds ${ }^{17}$ (Figure 2). 


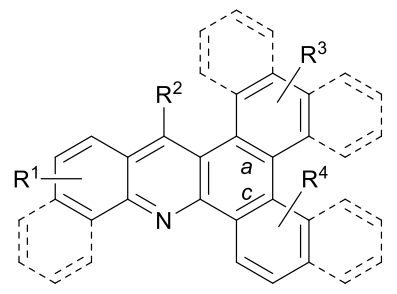

Figure 2 Dibenzo[ $a, c]$ acridines already prepared. ${ }^{16,17}$

We recently showed that substrates such as 2aminobenzaldehyde ${ }^{18}$ and 2 -aminophenones ${ }^{19}$ could be converted into either acridines, by $\mathrm{N}$-arylation and subsequent cyclization, or acridones, by double $\mathrm{N}$-arylation followed by cyclization. Inspired by these results, we here report how similar anilines can react with 2iodotriphenylene in order to deliver new PAHs based on acridine or acridone for which the photophysical properties were studied. In addition, due to their similarity with 9-aminoacridine (9AA) which is the reference matrix for negative mode MALDI, ${ }^{20}$ two of the helicene-like compounds here prepared were evaluated for this purpose.

\section{Results and discussion}

\subsection{Synthesis of acridine-based polycyclic aza-aromatics}

In the course of a study dedicated to the synthesis of acridines, ${ }^{18}$ we observed (as already noticed by others) ${ }^{21,} 22$ that the cyclization of both $N, N^{\prime}$-(1,3-phenylene)bis(2-aminobenzaldehyde) and $N, N^{\prime}-(1,4-$ phenylene)bis(2-aminobenzaldehyde) to dibenzophenanthrolines was regioselective, as displayed in Scheme 1 . Inspired by a study on aromatic electrophilic substitution $\left(\mathrm{S}_{\mathrm{E}} \mathrm{Ar}\right)$ of condensed imidazole derivatives, ${ }^{23}$ we applied the Fukui's concept (reaction of a compound with an electrophile at its carbon with the highest HOMO coefficient), ${ }^{24}$ and rationalized these experimental results by performing Hückel theory calculations on A, B and C (see ESI). ${ }^{25}$

This led us to consider the access to original helicene-like scaffolds ${ }^{26}$ based on acridine by using a similar approach, i.e. (i) $\mathrm{N}$ arylation of 2-aminobenzaldehyde, or 2-aminophenones, with 2iodotriphenylene followed by (ii) acid-mediated cyclization to afford polycyclic aza-aromatics. Indeed, as shown in Scheme 2, even if the difference is less marked than before between both possible cyclization sites, an intramolecular $S_{E} A r$ reaction at the most hindered position is favoured under orbital or charge control.

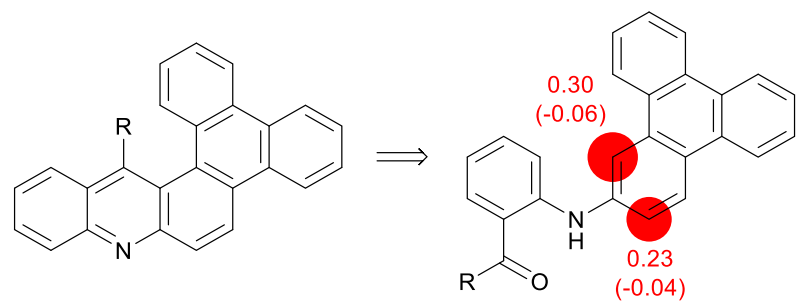

Scheme 2 Retrosynthetic plan to helicene-like scaffolds based on acridine and amplitudes of the HOMO coefficients and charges (in brackets) obtained (same values for $\mathrm{R}=\mathrm{H}, \mathrm{Me}, \mathrm{Ph}, \mathrm{OH}$ or $\mathrm{Cl}$ ) by using the HuLiS calculator ${ }^{27}$ (see ESI for more details).
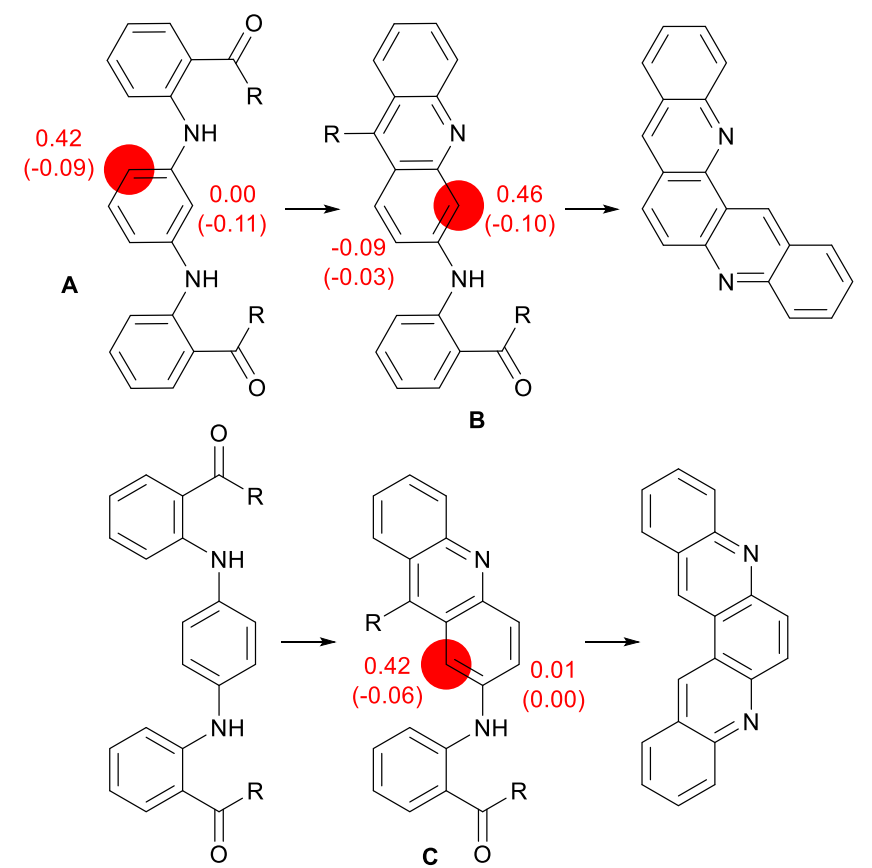

Scheme 1 Amplitudes of the highest occupied molecular orbital (HOMO) coefficients and charges (in brackets) obtained by using the HuLiS calculator ${ }^{27}$ to rationalize the regioselective formation of dibenzophenanthrolines $(R=H$ or Me).

Under acidic conditions, ${ }^{28}, 29$ the cyclization of the 2(triphenylenyl)aminobenzaldehyde $\mathbf{1}$ (prepared by $N$-arylation ${ }^{18,19,} 30$ of 2-aminobenzaldehyde using 2-iodotriphenylene) took place regioselectively to provide the expected phenanthro[9,10-a]acridine (2) in high yield. Its structure, already established by NMR (NOESY correlation observed between $\mathrm{H} 1$ and $\mathrm{H} 16$ ), was confirmed by X-ray diffraction (Scheme 3). Note that our attempt to perform the cyclization under smoother conditions, by using catalytic trifluoromethanesulfonic acid (10 mol\%) in 1,1,1,3,3,3-hexafluoro-2propanol $^{31}$ at room temperature overnight, also led to the polycyclic aza-aromatic 2 but in a lower $47 \%$ yield.

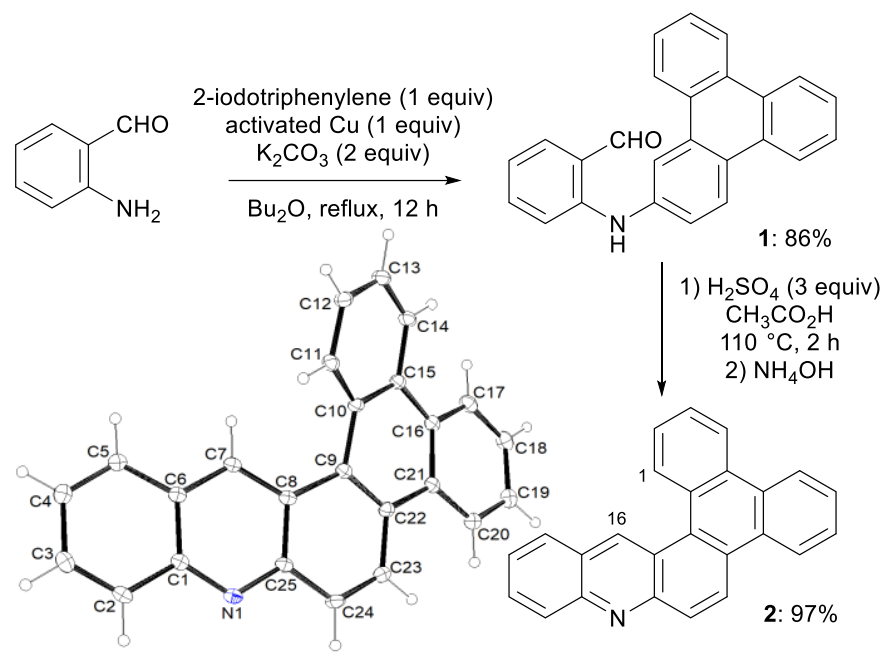

Scheme 3 Synthesis and ORTEP diagram (30\% probability) of phenanthro[9,10-a]acridine (2). 


\section{ARTICLE}

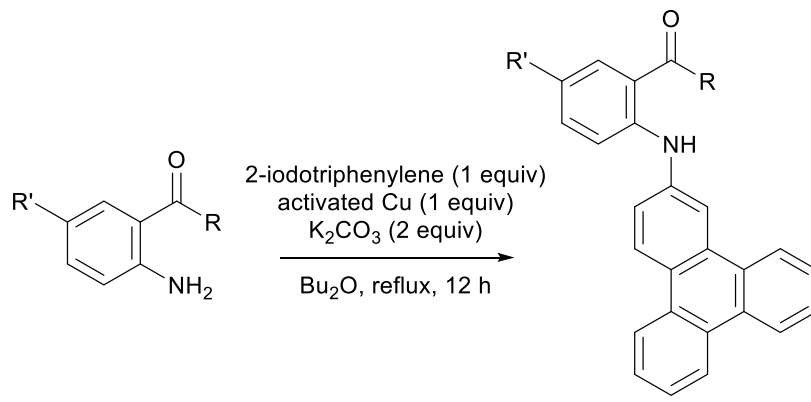

3a $\left(\mathrm{R}=\mathrm{Ph}, \mathrm{R}^{\prime}=\mathrm{H}\right): 71 \%$ 3b $\left(R=P h, R^{\prime}=C l\right): 91 \%$ $3 c\left(R=M e, R^{\prime}=H\right): 66 \%$

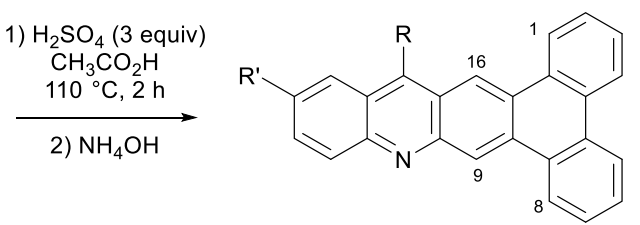

$4 a\left(R=P h, R^{\prime}=H\right): 57 \%$ 4b $\left(R=P h, R^{\prime}=C l\right): 95 \%$ $4 c\left(R=M e, R^{\prime}=H\right): 90 \%$

Scheme 4 Synthesis of the phenanthro[9,10-b]acridines 4 .

In contrast, by starting from 2-aminophenones, the $\mathrm{N}$-arylationcyclization sequence rather led to the phenanthro[9,10-b]acridines 4 in good yields. This was established unambiguously from the NMR spectra of $\mathbf{4 b}$, owing to the NOESY correlations observed between $\mathrm{H} 1$ and $\mathrm{H} 16$, and between $\mathrm{H} 8$ and $\mathrm{H} 9$ (Scheme 4). A more important steric hindrance in the case of ketones when compared with aldehyde, hampering an orbital control of the reaction, could be advanced to rationalize the regioselectivity switch observed.

Various attempts to functionalize compound $\mathbf{2}$ at its 16-position proved unsuccessful. For example, our efforts to introduce an amino group, as reported for the conversion of acridine into its 9-amino derivative (urea and sodium hydride in dimethylsulfoxide), ${ }^{32}$ only led to the recovery of the starting material. Similarly, our attempt to oxidize $\mathbf{2}$ into the corresponding acridone, as reported in the case of acridines (sodium hydride in dimethylsulfoxide), ${ }^{33}$ failed (starting material recovered, even after heating at $80^{\circ} \mathrm{C}$ overnight).

As an alternative way to generate 16-substituted phenanthro[9,10- $a$ ]acridines, we considered the 16-chloro derivative as starting point. This would in turn be accessible from the corresponding phenanthro[9,10-a]acridones. Indeed, compared with that of a ketone function, steric hindrance of the acyl chloride required for its synthesis should be reduced. However, our attempts to oxidize the aldehyde $\mathbf{1}$ into the corresponding carboxylic acid failed, for example by using iodine and potassium hydroxide in acetonitrile ${ }^{34}$ (very low conversion), or with sodium chlorite in the presence of 2-methyl-2-butene and sodium dihydrogenophosphate in tert-butanol-water ${ }^{35}$ (no reaction). Similarly, the conversion of the aldehyde into the ethyl ester $\mathbf{5}$, by using iodine and potassium hydroxide in ethanol, ${ }^{34}$ failed (very low conversion).

Thus, we selected ethyl anthranilate to perform its $\mathrm{N}$-arylation ${ }^{30}$, 36 with 2-iodotriphenylene towards the diarylamine $\mathbf{5}$, isolated in $88 \%$ yield. After hydrolysis of the ester function, ${ }^{37}$ the carboxylic acid 6 was treated by phosphorus(V) oxychloride under reflux ${ }^{37}$ for 3 days.
Under these conditions, the expected chloride 7 was obtained in $84 \%$ yield (Scheme 5).

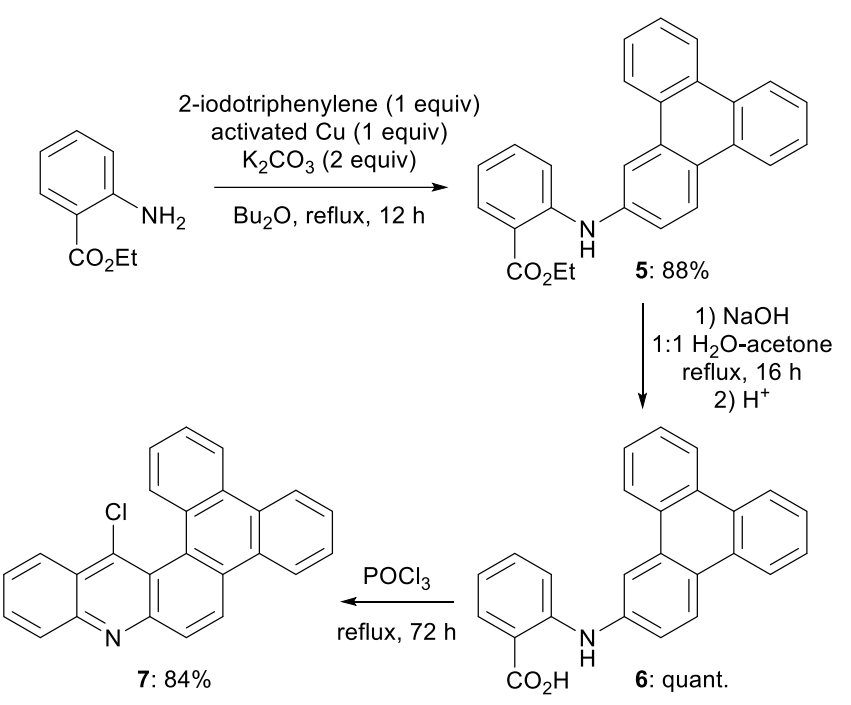

Scheme 5 Synthesis of 16-chlorophenanthro[9,10-a]acridine (7).

The replacement of chlorine of 9-chloroacridine by an amino group is documented in the literature, and notably by employing ammonium carbonate in phenol at $120^{\circ} \mathrm{C} .{ }^{38}$ However, when applied to the chloride 7 , the procedure did not furnish any amino derivative, but provided instead the phenyl ether 8 (Scheme 6, top).

Then, alternative ways to access the amino derivative were tested. The treatment of $\mathbf{7}$ with an excess of ammonia in dimethylsulfoxide at $120{ }^{\circ} \mathrm{C}$ (sealed tube) did not give the amino derivative satisfactorily (starting material was mainly recovered while degradation was noticed). Reaction of $\mathbf{7}$ with allylamine (used at solvent) at $60^{\circ} \mathrm{C}$ (sealed tube) afforded the allylamino derivative to some extent, but the subsequent cleavage of the allyl group 
(methanesulfonic acid and palladium on charcoal in ethanol under reflux) did not allowed the expected amino derivative to be isolated.

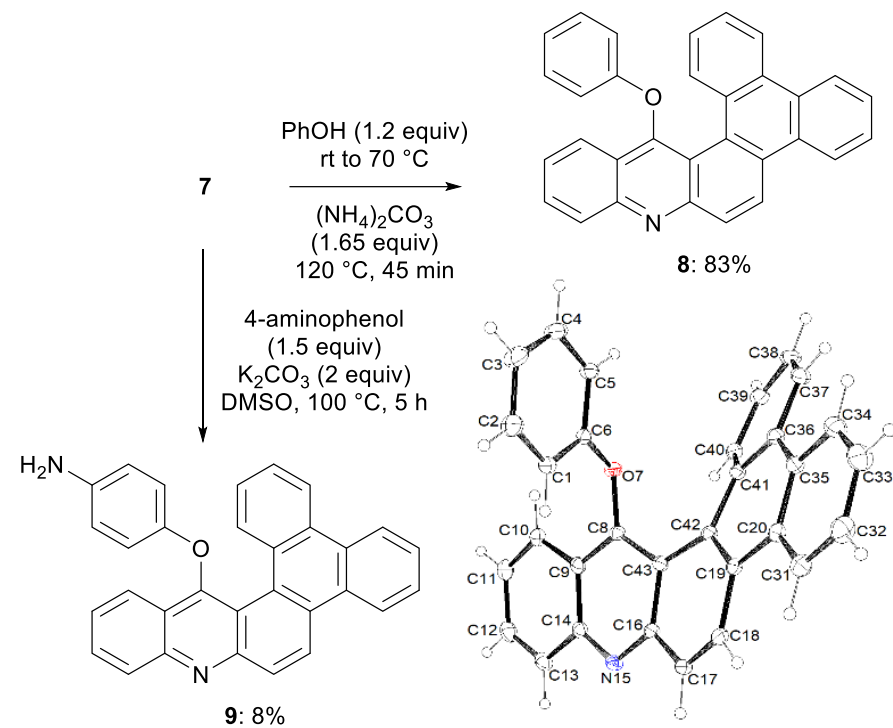

Scheme 6 Conversion of 16-chlorophenanthro[9,10-a]acridine (7) and ORTEP diagram (30\% probability) of 16-phenoxyphenanthro[9,10-a]acridine (9).

Finally, because the aryl ether $\mathbf{8}$ was easily obtained, we attempted the reaction of 4 -aminophenol with the chloride $\mathbf{7}$ in the presence of a base. By performing the reaction in dimethylsulfoxide at $100{ }^{\circ} \mathrm{C}, 39$ the aminoether 9 was formed. However, due to difficult purification, it was isolated in a low $8 \%$ yield (Scheme 6, bottom).

To prepare polycyclic aza-aromatics based on triphenylene and $\mathrm{NH}$-free acridone, we first examined the mono- $\mathrm{N}$-arylation of anthranilic acid with 2-iodotriphenylene, and the subsequent cyclization using polyphosphoric acid as described in similar cyclizations, ${ }^{40}$ but we failed in isolating a triphenylene-based acridone by following this approach. Because Zhou and co-workers succeeded in cyclizing 2-(phenylamino)acetophenone into $\mathrm{NH}$-free acridone by using copper(I) iodide ( 0.2 equiv) in dimethylsulfoxide at $140{ }^{\circ} \mathrm{C}$ under air atmosphere, ${ }^{41}$ we attempted a similar reaction from the ketone $3 \mathrm{c}$. However, after $36 \mathrm{~h}$, a complex mixture was obtained from which a $\mathrm{NH}$-free acridone could not be detected.

These failures led us to rather turn to the synthesis of $\mathrm{N}$ substituted triphenylene-based acridones. To this goal, we first attempted the cyclization of the ketones $\mathbf{3} \mathbf{a}$ and $\mathbf{3} \mathbf{b}$ in the presence of copper(I) iodide ( 0.2 equiv) in dimethylsulfoxide at $120^{\circ} \mathrm{C}$ under air since these conditions were employed by Zhou and Deng to convert 2-(phenylamino)benzophenone into $\mathrm{N}$-phenylacridone. ${ }^{42}$ However, these conditions failed in delivering the expected products.

Consequently, we capitalized on the possible double coppercatalysed $\mathrm{N}$-arylation of 2-aminobenzaldehyde we recently reported. ${ }^{18}$ By reaction with 2 -iodotriphenylene (2 equiv) in the presence of an excess of base ( 3 equiv) in refluxing diethyl ether for $24 \mathrm{~h}$, the aldehyde 10 was obtained in $62 \%$ yield (Scheme 7, top). Next, we studied its cyclization, and first tested the acidic conditions employed to convert the compounds 3 into 4 ; however, degradation took place, and no acridone could be isolated.
In 2013, Yang and co-workers cyclized $N$-methyl- $N$-phenyl-2aminobenzaldehydes into $\mathrm{N}$-methylacridones by recourse to catalytic ytterbium(III) triflate or scandium(III) triflate in the presence of sodium sulfate in dimethylformamide at $100{ }^{\circ} \mathrm{C} .{ }^{43}$ Inspired by this work, we applied the protocol using ytterbium(III) triflate, and observed the formation of the $\mathrm{N}$-triphenylated triphenylene-based acridone 11. However, it proved difficult to purify this compound which was only isolated in a low $10 \%$ yield by recrystallization from ethyl acetate (Scheme 7, bottom).

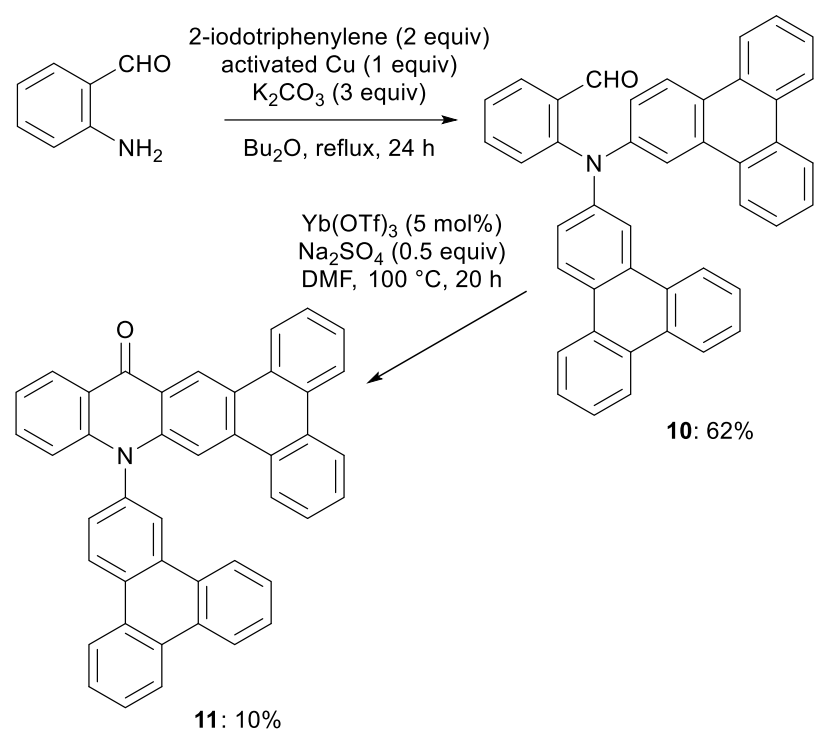

Scheme 7 Synthesis of $N$-(2-triphenylenyl)phenanthro[9,10- $b]$-15-acridone (11).

To rationalize the regioselectivity of the reaction, which probably takes place by intramolecular $S_{E} A r$ reaction followed by oxidation, ${ }^{43}$ we calculated as above both amplitudes of the HOMO coefficients and charges on the aldehyde $\mathbf{1 0}$ (see ESI and Scheme 8, left). Albeit in favour of the most hindered position, the difference between both cyclization sites on the triphenylene ring is not very marked and steric effects might become predominant. This is probably why a helicene-like acridone was not formed in this case.

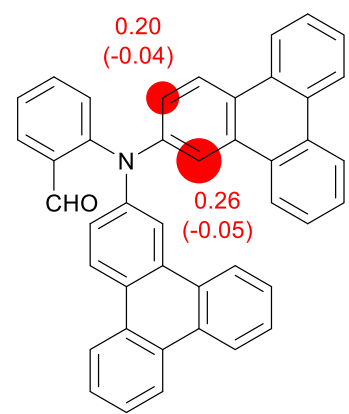

10

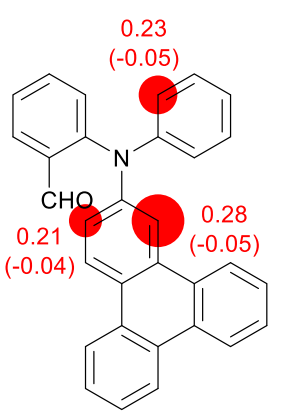

12
Scheme 8 Amplitudes of the highest occupied molecular orbital (HOMO) coefficients and charges (in brackets) obtained by using the HuLiS calculator ${ }^{27}$ to rationalize the regioselective formation of the acridones $\mathbf{1 1}$ and $\mathbf{1 3 .}$ 
Similar calculations performed on the aldehyde $\mathbf{1 2}$ show a not very marked difference between the phenyl and the less hindered 2triphenylenyl possible cyclization sites (see ESI and Scheme 8, right). Since there is also no peculiar difference between both sides regarding steric hindrance, a cyclization involving the phenyl ring might be expected. We therefore decided to synthesize the aldehyde 12.

To attain compound $\mathbf{1 2}$, it is possible to successively $\mathrm{N}$-arylate 2 aminobenzaldehyde by using iodobenzene and 2-iodotriphenylene. In our hands, the first $\mathrm{N}$-arylation under the conditions used in Scheme 3 to prepare 1 afforded 2-(phenylamino)benzaldehyde ${ }^{18}$ in $86 \%$ yield; however, the second $\mathrm{N}$-arylation using 2-iodotriphenylene proceeded in a low $22 \%$ yield (not shown).

When we reversed the step order, and thus involved 1 and iodobenzene, we could obtain $\mathbf{1 2}$ more satisfactorily (Scheme 9, top). Then, the cyclization of $\mathbf{1 2}$ was performed as before, by using either ytterbium(III) triflate or scandium(III) triflate, and the predicted acridone 13 was isolated in $83 \%$ yield (Scheme 9, bottom) and 64\% yield (not shown), respectively. It is worth noting that $N$-arylation of acridone by using 2-iodotriphenylene (1.5 equiv) in the presence of potassium carbonate ( 2 equiv), copper(I) iodide ( 0.20 equiv) and 2,2,6,6-tetramethyl-3,5-heptanedione $\quad(0.40$ equiv $)$ in dimethylformamide at reflux for $24 \mathrm{~h}$, as reported to access nitrogenembedded quinoidal pentacenes, ${ }^{44}$ only allowed us to isolate $\mathbf{1 3}$ in $8 \%$ yield (not shown).

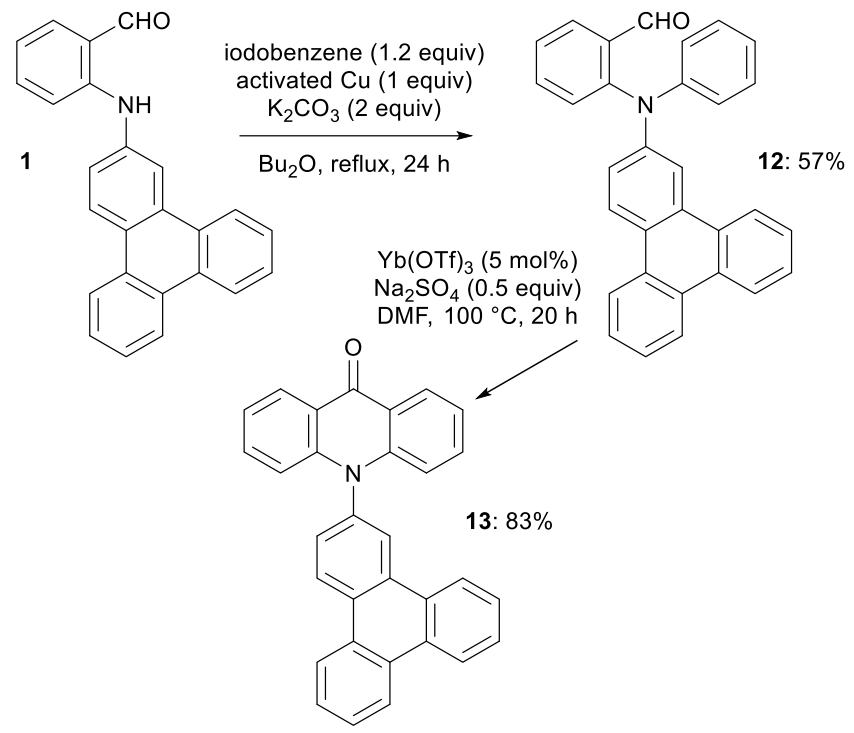

Scheme 9 Synthesis of $\mathrm{N}$-(2-triphenylenyl)-9-acridone (13).

\subsection{Qualitative evaluation of acridine-based polycyclic aza- aromatics as matrices for MALDI-MS}

With the structural similarity of 8 and $\mathbf{9}$ with 9-aminoacridine (9AA), the gold standard matrix for negative mode in MALDI-MS, ${ }^{20}$ and azahelicenes which were described as potential candidates for MALDI or MAILD matrices, ${ }^{45}$ we compared the ability of $\mathbf{8}$ and $\mathbf{9}$ to ionize a group of nine target compounds (mainly drugs, see ESI). Therefore, we designed a quick MALDI-MS method with the idea to focus on qualitative detection. We performed the experiments in both positive and negative mode, with the five different matrices
DCTB, HCCA, 9-AA, 8 and 9, with two solvents for a two-layer spotting ${ }^{46}$ (90 spots and 180 experiments). Each experiment aimed to reach 500 counts on the base peak by increasing gradually the laser power. A better quality of MALDI mass spectra in term of resolution and exact mass precision is achieved within the little power as possible, this phenomenon is called irradiance or fluence. ${ }^{47}$ We scaled this factor [Laser(+) or Laser(-)] from zero (upper than $66 \%$ of laser power) up to six (less than $15 \%$ ). The goal was to obtain target compounds as base peaks, but if not possible, the relative intensity was exported. We scaled this factor [Target.in(+) or Target.in(-)] from zero (not seen) up to five (seen as base peak). A product factor [Product.LT] representing both the laser power applied and the presence of target compounds was calculated. We scaled specifically a factor [Target.BP(+), Target.BP(-) or Target.BP] representing the number of target compounds obtained as a base peak, in positive, negative or in both, without redundancy. The solvent influence was not relevant.

At the first sight, the Kiviat's diagram of average values of the factors for the five matrices shows that DCTB was surprisingly the best matrix in both ionization modes. 9-AA has slightly higher result in term of overall ionization of target compounds in negative mode but the ionization efficiency is bad (Figure 3).

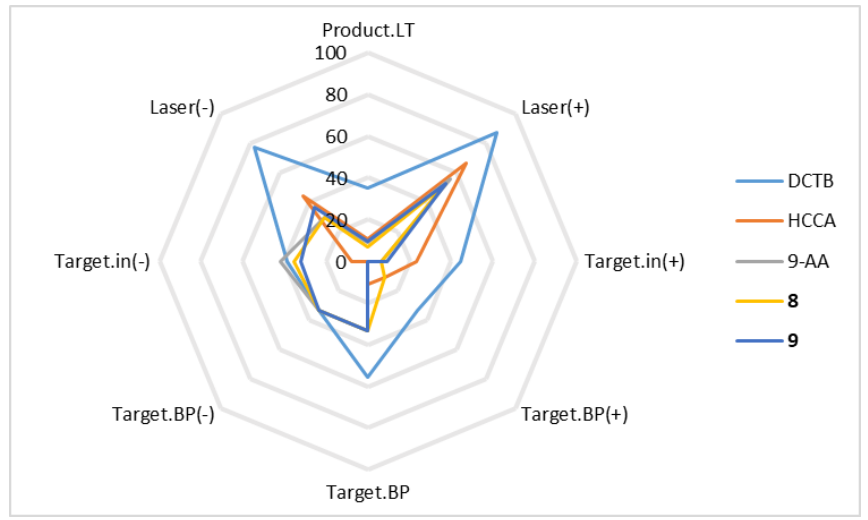

Figure 3

Qualitative analysis of the five matrices.

For more details, HCCA is a matrix mainly applied for positive mode in MALDI-MS. The Kiviat's diagram of average values for DCTB vs. HCCA matrices shows that HCCA ionized one target compound only in positive mode as expected, in comparison DCTB is the best in positive mode with three target compounds as base peak (see Figure 4). In a matter of fact, in this experiment DCTB is better than HCCA in positive ionization.

9-AA is the gold standard matrix for negative mode in MALDIMS. ${ }^{20}$ The Kiviat's diagram of average values for DCTB vs. 9-AA matrices shows that 9-AA was suitable to ionize three target compounds only in negative mode as expected, in comparison DCTB has also three target compounds as base peak (see ESI and Figure 5). 9-AA has slightly higher result in term of overall ionization of target compounds in negative mode (Target.in(-): 9-AA (42.2\%) and DCTB $(38.8 \%)$ ). But DCTB ionization efficiency is really better (Laser(-): DCTB (76.8\%) and 9-AA (29.5\%)). In this work, DCTB is a better matrix than 9-AA in negative ionization. 


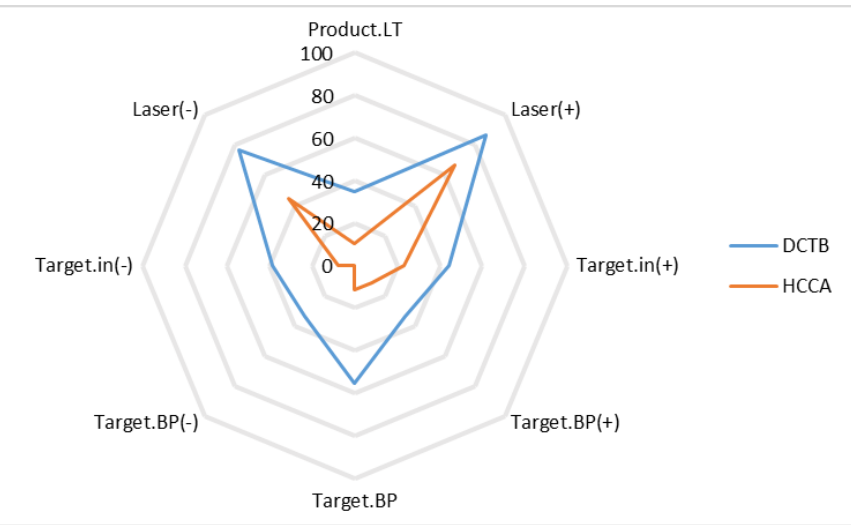

Figure 4 Qualitative analysis of DCTB vs. HCCA.

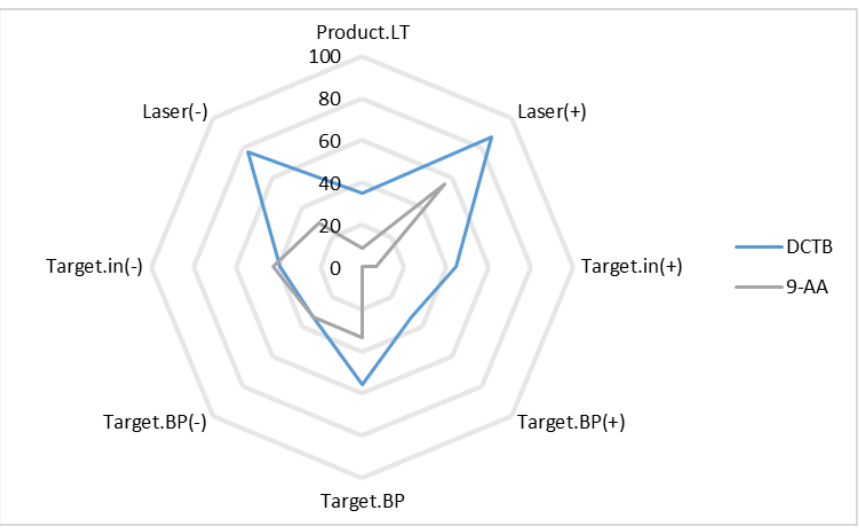

Figure 5 Qualitative analysis of DCTB vs. 9-AA.

For the comparison between 9-AA, 8 and 9, the Kiviat's diagram shows that the three matrices were suitable to ionize three target compounds in negative mode as expected (see ESI and Figure 6). Although 9-AA gave the best result in term of overall ionization of target compounds in negative mode (Target.in(-) 9-AA (42.2\%), 8 $(35.6 \%)$ and $9(32.2 \%))$, the ionization efficiency of 9 is promising (Laser(-) 9 (36.2\%) vs. 8 (29.7\%) and 9-AA (29.5\%)).

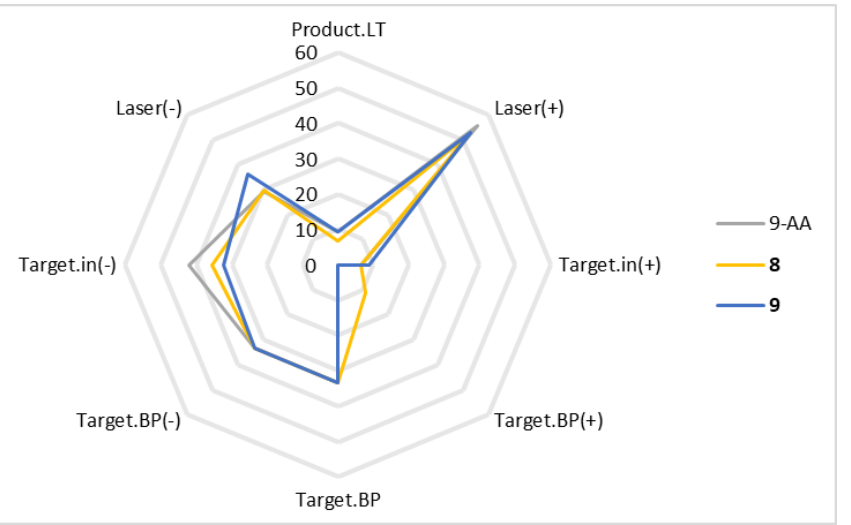

Figure 6 Qualitative analysis of 9-AA, 8 and $\mathbf{9 .}$

\subsection{Photophysical properties of the synthesized acridine- and acridone-based aza-polycycles}

Both acridine and acridone derivatives can display interesting fluorescence properties, in particular when substituted by electrondonating groups. ${ }^{18,} 48$ Thus, to establish structure-properties relationships, preliminary studies of the photophysical properties of most of the nitrogen-containing polycycles were performed. Their UV-visible absorption and emission properties were investigated in toluene, and the results are gathered in Table 1.

Table 1 Absorption and emission properties of phenanthroacridines $\mathbf{2}$, 4, 7, 8 and acridones 11,13 in toluene at $25^{\circ} \mathrm{C}$.

\begin{tabular}{|c|c|c|c|c|}
\hline Compound & $\begin{array}{c}\lambda_{\text {abs }} \\
(\mathrm{nm})\end{array}$ & $\begin{array}{c}\varepsilon_{\max } \\
\left(\mathrm{M}^{-1} \mathrm{~cm}^{-1}\right)\end{array}$ & $\begin{array}{c}\lambda_{\mathrm{em}} \\
(\mathrm{nm})\end{array}$ & $\Phi_{\mathrm{F}}$ \\
\hline $\mathbf{2}$ & 392 & 9480 & 447 & 0.06 \\
\hline $\mathbf{4 a}$ & 414 & 14300 & 465,495 & 0.30 \\
\hline $\mathbf{4 b}$ & 419 & 8700 & 469,499 & 0.30 \\
\hline $\mathbf{4 c}$ & 412 & 12000 & $456,485,520$ & 0.14 \\
\hline $\mathbf{7}$ & 406 & 11500 & 467 & 0.02 \\
\hline $\mathbf{8}$ & 399 & 11000 & 463 & 0.05 \\
\hline $\mathbf{1 1}$ & 436 & 4760 & 445,473 & 0.08 \\
\hline $\mathbf{1 3}$ & 391 & 8940 & 398,420 & 0.03 \\
\hline
\end{tabular}

The three phenanthrol $[9,10-a]$ acridines $\mathbf{2 ,} \mathbf{7}$ and $\mathbf{8}$ exhibit similar absorption and emission properties, i.e. a lowest energy absorption band in the 350-450 nm range, with molar extinction coefficients of $\sim 10^{4} \mathrm{M}^{-1} \mathrm{~cm}^{-1}$, and an unresolved emission band in the violet-blue part of the visible (Figure 7). Substitution at 16-position leads to bathochromic shifts in both absorption and emission, with larger shifts with chloro (7) than with phenoxy (8). Their fluorescence quantum yields are rather low (2-6\%), probably in relation with their non-planar helicene-like shape.

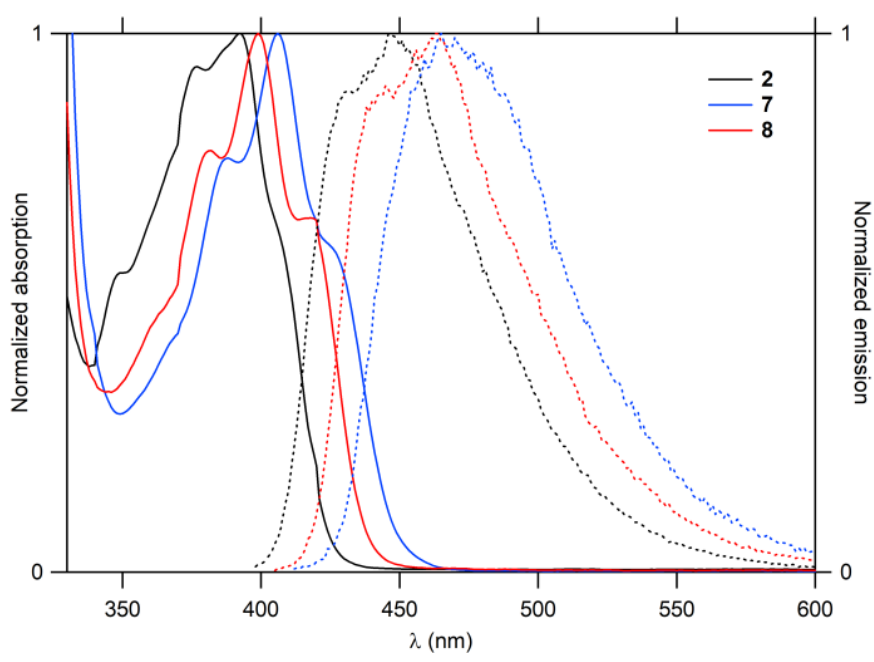

Figure 7 Absorption (solid line) and emission (dotted line) of phenanthrol[9,10- $a]$ acridines $\mathbf{2 , 7}$ and $\mathbf{8}$ in toluene.

The three phenanthrol[9,10- $b]$ acridines $4 a-c$ exhibit a structured absorption band with a maximum at around $415 \mathrm{~nm}$ and a structured emission band in the blue-green part of the visible (Figure 8). Introduction of a chlorine atom at the 13-position leads to small red- 
shifts of the absorption ( $5 \mathrm{~nm}$ ) and emission $(4 \mathrm{~nm})$ bands, whereas replacement of a phenyl ring by a weaker donor methyl group at the 15-position has almost no effect on the absorption but leads to a 10 $\mathrm{nm}$ blue-shift of the emission band. The fluorescence quantum yields of $4 a-c$ range between 14 and 30\%. These compounds are therefore clearly more emissive than the helicene-like compounds 2, $\mathbf{7}$ and 8, in relation with their better planarity.

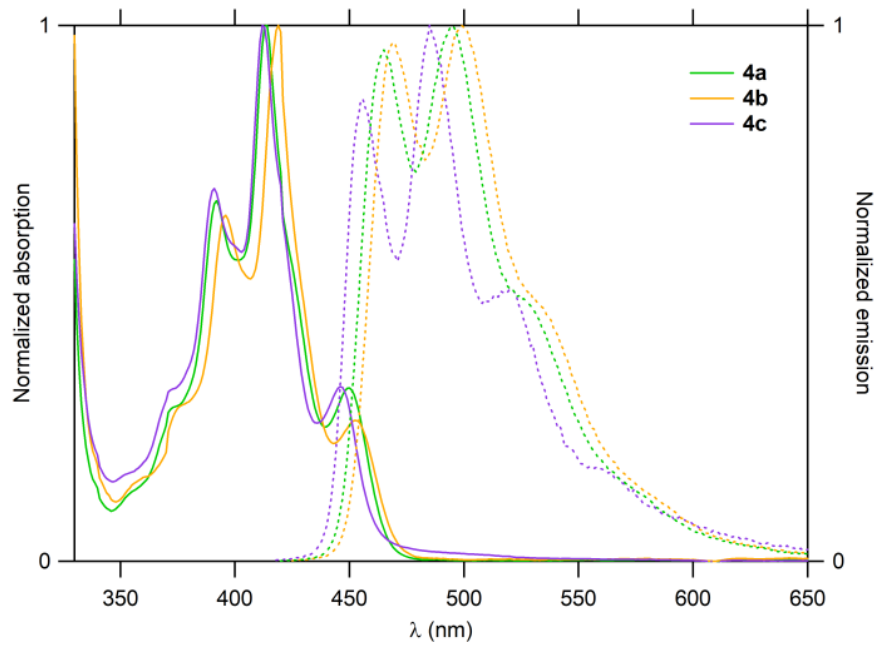

Figure 8 Absorption (solid line) and emission (dotted line) of phenanthrol $[9,10-b]$ acridines $4 a-c$ in toluene.

Phenanthrol[9,10- $b]$ acridone $\mathbf{1 1}$ and acridone $\mathbf{1 3}$ exhibit similar fine-structured lowest energy absorption and emission bands, but those of compound $\mathbf{1 1}$ are strongly red-shifted $(45 \mathrm{~nm}$ in absorption and $47 \mathrm{~nm}$ in emission), in relation with the extended $\pi$-electron system of $\mathbf{1 1}$ in comparison with that of $\mathbf{1 3}$ (Figure 9). This extension also leads to a significant increase of the fluorescence quantum yield from $3 \%$ for 13 to $8 \%$ for 11 .

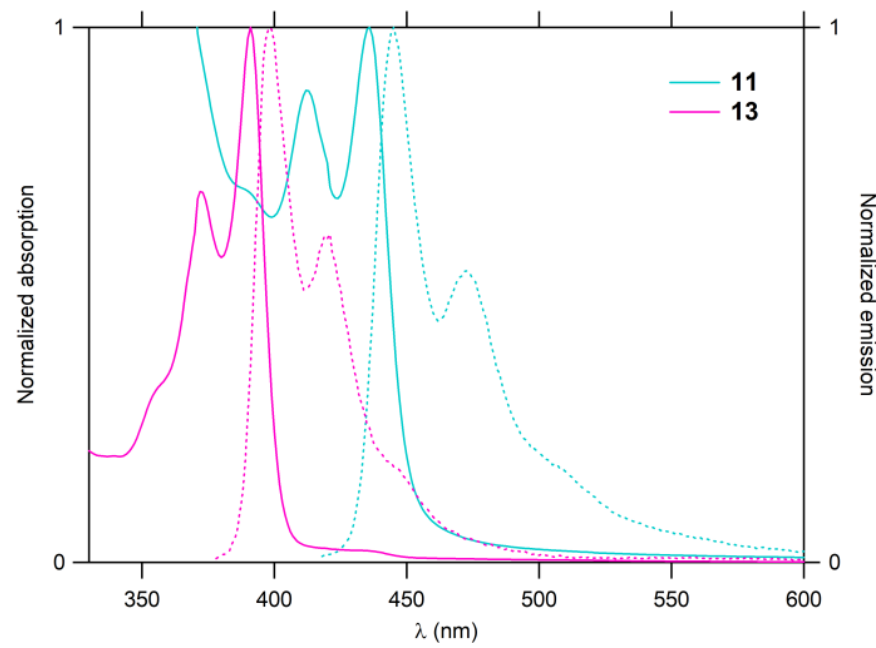

Figure 9 Absorption (solid line) and emission (dotted line) of acridones 11 and 13 in toluene.

\section{Conclusions}

Thus, in the present study, we evidenced the value of coppercatalysed $\mathrm{N}$-arylation of anilines bearing an adjacent carbonylated function to access nitrogen-containing polyaromatic hydrocarbons (PAHs). Interestingly, the cyclization to PAHs occurred regioselectively; while formation of helicene-like scaffolds was observed in some cases (which corresponds to both orbital and charge controls), more linear polycycles prevailed from bulkier precursors.

Regarding the unexpected results obtained with DCTB as a MALDI-MS matrix, the introduction of a trans-2-[2-methyl-2propenyliden-3-yl]malononitrile group $\left(\mathrm{R}-\mathrm{CH}=\mathrm{C}\left(\mathrm{CH}_{3}\right)\right.$ $\mathrm{CH}=\mathrm{C}(\mathrm{CN})_{2}$ ) on our original PAHs could be a promising strategy to reach more efficient matrices. Besides, other applications for the prepared aza-polycycles could be expected. Indeed, the introduction of heteroatoms, and in particular nitrogen, in nanographenes (which behave as graphene segments) can have a great impact on their properties (e.g. resistance to oxidation and dimerization, ability to molecular packing, optical and electrochemical behaviours, etc.), and can be used to tune them. ${ }^{49}$ Therefore, as our strategy is able to easily deliver azapolycycles, further development could be expected. Efforts are actually ongoing and will be reported in due course.

\section{Experimental}

The general information, synthetic procedures and analyses of the intermediates can be found in the ESI. +

\section{Synthesis of the compounds 2 and 4 (General procedure).}

They were prepared by adapting a literature procedure. ${ }^{28}$ To 2(2-triphenylenyl)aminobenzaldehyde (1; $0.37 \mathrm{~g}, 1.0 \mathrm{mmol})$, or the required 2-(2-triphenylenyl)aminophenone $(1.0 \mathrm{mmol})$, in $\mathrm{CH}_{3} \mathrm{CO}_{2} \mathrm{H}(3 \mathrm{~mL})$ was added $96 \% \mathrm{H}_{2} \mathrm{SO}_{4}(2.8 \mathrm{mmol}, 0.15 \mathrm{~mL})$. The mixture was stirred at $110{ }^{\circ} \mathrm{C}$ for $2 \mathrm{~h}$. After cooling to room temperature, water $(5 \mathrm{~mL})$ was added and the mixture was basified using $25 \% \mathrm{NH}_{4} \mathrm{OH}$ before extraction using AcOEt ( $3 \times 20$ $\mathrm{mL}$ ), drying over $\mathrm{MgSO}_{4}$, and removal of the solvent. The crude was purified as specified in the product description.

Phenanthro[9,10-a]acridine (2). It was prepared according to the general procedure by starting from 2-(2triphenylenyl)aminobenzaldehyde (1). Purification by column chromatography on silica gel (eluent: petroleum ether-AcOEt 80:20; $\left.R_{f}=0.375\right)$ gave 2 in $97 \%$ yield $(0.34 \mathrm{~g}$ ) as a yellow solid: $\mathrm{mp} 224^{\circ} \mathrm{C}$; IR (ATR): 723, 747, 766, 828, 856, 929, 965, 1144, $1244,1373,1418,1433,1477,1495,1523,1539,1610,1717$, 1965, 2850, 2919, $3059 \mathrm{~cm}^{-1}$; ${ }^{1} \mathrm{H}$ NMR $\left(\mathrm{CDCl}_{3}\right) \delta 7.59(\mathrm{t}, 1 \mathrm{H}, \mathrm{J}=$ $7.45 \mathrm{~Hz}, \mathrm{H} 14), 7.69$ and 7.71-7.75 (t, $1 \mathrm{H}, J=7.0 \mathrm{~Hz}$ and $\mathrm{m}, 3 \mathrm{H}$, $\mathrm{H} 2, \mathrm{H} 3, \mathrm{H} 6$ and $\mathrm{H} 7), 7.85(\mathrm{t}, 1 \mathrm{H}, J=7.6 \mathrm{~Hz}, \mathrm{H} 13), 8.05(\mathrm{~d}, 1 \mathrm{H}, J=$ $8.3 \mathrm{~Hz}, \mathrm{H} 15), 8.31(\mathrm{t}, 2 \mathrm{H}, J=8.6 \mathrm{~Hz}, \mathrm{H} 10$ and $\mathrm{H} 12), 8.62-8.64(\mathrm{~m}$, $1 \mathrm{H}, \mathrm{H} 8), 8.71-8.73$ and $8.77(\mathrm{~m}, 1 \mathrm{H}$ and $\mathrm{t}, 2 \mathrm{H}, J=8.1 \mathrm{~Hz} ; \mathrm{H} 1, \mathrm{H} 4$ and $\mathrm{H} 5), 8.83(\mathrm{~d}, 1 \mathrm{H}, \mathrm{J}=9.4 \mathrm{~Hz}, \mathrm{H} 9), 9.66(\mathrm{~s}, 1 \mathrm{H}, \mathrm{H} 16) ;{ }^{13} \mathrm{C} \mathrm{NMR}$ $\left(\mathrm{CDCl}_{3}\right) \delta 123.3(\mathrm{CH}), 123.8(\mathrm{C}), 123.8(\mathrm{CH}), 123.9(\mathrm{CH}), 126.0$ (CH, C14), 126.2 (C), 126.3 (CH, C9), 126.8 (CH), 127.0 (C), 127.1 $(\mathrm{CH}), 127.3(\mathrm{C}), 127.7(\mathrm{CH}), 127.8(\mathrm{CH}), 128.7(\mathrm{CH}, \mathrm{C} 15), 128.9$ 
(CH), $129.0(\mathrm{CH}), 129.1$ (CH), 129.2 (C), 129.4 (C), 130.3 (C), 130.7 (CH), 131.3 (C), 137.0 (CH, C16), 148.0 (C), 149.5 (C); HRMS (MALDI, DCTB matrix), $\mathrm{m} / \mathrm{z}: 330.127$ (2 ppm) found (calcd for $\mathrm{C}_{25} \mathrm{H}_{16} \mathrm{~N},[\mathrm{M}+\mathrm{H}]^{+}$, requires 330.1277$)$. Crystal data for 2 . $\mathrm{C}_{25} \mathrm{H}_{15} \mathrm{~N}, M=329.38$, monoclinic, $P 2{ }_{1} / c, a=12.054(2), b=$ 10.6413(10), $c=13.5706(19) \AA, b=114.096(9)^{\circ}, V=1589.1(4)$ $\AA^{3}, Z=4, d=1.377 \mathrm{~g} \mathrm{~cm}^{-3}, \mu=0.080 \mathrm{~mm}^{-1}$. A final refinement on $F^{2}$ with 3521 unique intensities and 235 parameters converged at $\omega R\left(F^{2}\right)=0.2049(R(F)=0.0563)$ for 2798 observed reflections with $I>2 \sigma(I)$. CCDC 2085922.

15-Phenylphenanthro[9,10-b]acridine (4a). It was prepared according to the general procedure by starting from phenyl 2 (2-triphenylenyl)aminophenyl ketone (3a; 0.44 g). Purification by column chromatography on silica gel (eluent: petroleum ether-AcOEt 80:20; $R_{f}=0.40$ ) gave $4 a$ in $57 \%$ yield $(0.23 \mathrm{~g})$ as an orange solid: $\mathrm{mp} 254^{\circ} \mathrm{C}$; IR (ATR): $702,718,757,782,873,923$, $1075,1262,1424,1491,1509,1534,1552,1626,2186,3064 \mathrm{~cm}^{-}$ ${ }^{1}$; ${ }^{1} \mathrm{H}$ NMR $\left(\mathrm{CDCl}_{3}\right) \delta$ 7.44-7.63 $(\mathrm{m}, 5 \mathrm{H}), 7.65-7.74(\mathrm{~m}, 5 \mathrm{H}), 7.82$ $(\mathrm{t}, J=8.5 \mathrm{~Hz}, 2 \mathrm{H}), 8.23(\mathrm{~d}, 1 \mathrm{H}, J=6.3 \mathrm{~Hz}), 8.34(\mathrm{~d}, 1 \mathrm{H}, J=7.2 \mathrm{~Hz})$, 8.48 (br s, 2H), 8.87 (br s, 1H), $8.91(\mathrm{~s}, 1 \mathrm{H}), 9.50(\mathrm{~s}, 1 \mathrm{H}) ;{ }^{13} \mathrm{C} \mathrm{NMR}$ $\left(\mathrm{CDCl}_{3}\right) \delta 121.2(\mathrm{CH}), 122.9(\mathrm{CH}), 123.6(\mathrm{CH}), 123.7(\mathrm{CH}), 124.0$ $(\mathrm{CH}), 124.3(\mathrm{C}), 124.8(\mathrm{CH}), 125.3(\mathrm{C}), 125.7(\mathrm{CH}), 127.1(\mathrm{CH})$, $127.8(\mathrm{CH}), 128.1(\mathrm{CH}), 128.3(\mathrm{CH}), 128.8(\mathrm{C}), 128.8(2 \mathrm{CH}), 128.8$ $(\mathrm{CH}), 128.9(\mathrm{CH}), 129.5(\mathrm{CH}), 129.8$ (C), 129.9 (C), $130.4(\mathrm{C})$, $130.5(\mathrm{CH}), 130.8$ (C), 130.9 (2CH), 132.9 (C), 136.0 (C), 147.0 (C), 147.7 (C), 149.6 (C); HRMS (MALDI, DCTB matrix), $m / z$ : $406.159(0 \mathrm{ppm})$ found (calcd for $\mathrm{C}_{31} \mathrm{H}_{20} \mathrm{~N},[\mathrm{M}+\mathrm{H}]^{+}$, requires 406.1590).

13-Chloro-15-phenylphenanthro[9,10-b]acridine (4b). It was prepared according to the general procedure by starting from 5-chloro-2-(2-triphenylenyl)aminophenyl phenyl ketone ( 3 b; 0.48 g). Purification by column chromatography on silica gel (eluent: petroleum ether-AcOEt 80:20; $R_{f}=0.525$ ) gave $4 b$ in $95 \%$ yield $(0.42 \mathrm{~g})$ as a yellow solid: $\mathrm{mp}>260^{\circ} \mathrm{C}$; IR (ATR): 717 , 754, 787, 821, 869, 878, 949, 970, 1029, 1067, 1135, 1164, 1256, $1307,1404,1421,1441,1487,1507,1599,1952,3064 \mathrm{~cm}^{-1} ;{ }^{1} \mathrm{H}$ NMR $\left(\mathrm{CDCl}_{3}\right) \delta 7.47$ (ddd, $1 \mathrm{H}, J=8.2,7.6$ and $\left.0.95 \mathrm{~Hz}\right), 7.53-7.57$ $(\mathrm{m}, 3 \mathrm{H}), 7.61-7.66(\mathrm{~m}, 3 \mathrm{H}), 7.70-7.74(\mathrm{~m}, 4 \mathrm{H}), 8.16(\mathrm{~d}, 1 \mathrm{H}, J=7.0$ $\mathrm{Hz}, \mathrm{H} 1), 8.23(\mathrm{~d}, 1 \mathrm{H}, J=9.1 \mathrm{~Hz}, \mathrm{H} 11), 8.40-8.44(\mathrm{~m}, 2 \mathrm{H}, \mathrm{H} 4$ and $\mathrm{H} 5), 8.76(\mathrm{dd}, 1 \mathrm{H}, J=6.0$ and $3.6 \mathrm{~Hz}, \mathrm{H} 8), 8.82(\mathrm{~s}, 1 \mathrm{H}, \mathrm{H} 16), 9.38$ $(\mathrm{s}, 1 \mathrm{H}, \mathrm{H} 9) ;{ }^{13} \mathrm{C} \mathrm{NMR}\left(\mathrm{CDCl}_{3}\right) \delta 121.0(\mathrm{CH}), 122.6(\mathrm{CH}), 123.6(\mathrm{CH})$, $123.7(\mathrm{CH}), 124.0(\mathrm{CH}), 124.3(\mathrm{C}), 129.2(\mathrm{CH}), 124.8(\mathrm{CH}), 125.2$ $(\mathrm{CH}), 125.3(\mathrm{C}), 127.8(\mathrm{CH}), 128.1(\mathrm{CH}), 128.5(\mathrm{CH}), 129.0(2 \mathrm{CH})$, $129.1(\mathrm{CH}), 129.3$ (C), 129.5 (C), 129.6 (C), 130.4 (C), 130.8 (C), $130.8(2 \mathrm{CH}), 130.9(\mathrm{CH}), 131.6(\mathrm{C}), 131.8(\mathrm{CH}), 133.2(\mathrm{C}), 135.3$ (C), 146.5 (C), 147.1 (C), 147.3 (C); HRMS (MALDI, DCTB matrix), $\mathrm{m} / \mathrm{z}: 440.120\left(0 \mathrm{ppm}\right.$ ) found (calcd for $\mathrm{C}_{31} \mathrm{H}_{19}{ }^{35} \mathrm{ClN},[\mathrm{M}+\mathrm{H}]^{+}$, requires 440.1200 )

15-Methylphenanthro[9,10-b]acridine (4c). It was prepared according to the general procedure by starting from 2-(2-triphenylenyl)aminoacetophenone (3c; $0.36 \mathrm{~g}$ ). Purification by recrystallization from AcOEt gave $4 \mathrm{c}$ in $90 \%$ yield (0.31 g) as an orange solid: $\mathrm{mp}>260^{\circ} \mathrm{C}$; IR (ATR): $717,751,857$, 947, 1052, 1261, 1424, 1509, 1551, 1664, 2166, $2921 \mathrm{~cm}^{-1} ;{ }^{1} \mathrm{H}$
NMR $\left(\mathrm{CDCl}_{3}\right)$ at a lower concentration (about $1 \mathrm{mg}$ in $\left.0.5 \mathrm{~mL}\right) \delta$ $3.35(\mathrm{~s}, 3 \mathrm{H}, \mathrm{Me}), 7.56(\mathrm{t}, 1 \mathrm{H}, J=7.6 \mathrm{~Hz}), 7.63-7.68(\mathrm{~m}, 4 \mathrm{H}), 7.79$ $(\mathrm{t}, 1 \mathrm{H}, J=7.5 \mathrm{~Hz}), 8.27(\mathrm{~d}, 1 \mathrm{H}, J=8.7 \mathrm{~Hz}), 8.30(\mathrm{~d}, 1 \mathrm{H}, J=8.8 \mathrm{~Hz})$, 8.52-8.53 (m, 2H), $8.77(\mathrm{~d}, 1 \mathrm{H}, J=7.5 \mathrm{~Hz}), 8.84-8.86(\mathrm{~m}, 1 \mathrm{H}), 9.44$ $(\mathrm{s}, 2 \mathrm{H}) ;{ }^{1} \mathrm{H} \mathrm{NMR}\left(\mathrm{CDCl}_{3}\right)$ at higher concentration (about $2 \mathrm{mg}$ in $0.5 \mathrm{~mL}) \delta 3.21(\mathrm{~s}, 3 \mathrm{H}, \mathrm{Me}), 7.49(\mathrm{t}, 1 \mathrm{H}, J=7.6 \mathrm{~Hz}), 7.58-7.63(\mathrm{~m}$, $4 \mathrm{H}), 7.74(\mathrm{t}, 1 \mathrm{H}, J=7.5 \mathrm{~Hz}), 8.20(\mathrm{t}, 2 \mathrm{H}, J=8.7 \mathrm{~Hz}), 8.43(\mathrm{~d}, 2 \mathrm{H}, J$ $=6.8 \mathrm{~Hz}), 8.63(\mathrm{~d}, 1 \mathrm{H}, J=6.8 \mathrm{~Hz}), 8.76(\mathrm{~d}, 1 \mathrm{H}, J=4.9 \mathrm{~Hz}), 9.25(\mathrm{~s}$, $1 \mathrm{H}), 9.31(\mathrm{~s}, 1 \mathrm{H}) ;{ }^{13} \mathrm{C} \mathrm{NMR}\left(\mathrm{CDCl}_{3}\right) \delta 14.0\left(\mathrm{CH}_{3}\right), 118.6(\mathrm{CH}), 123.5$ $(\mathrm{CH}), 123.7(\mathrm{CH}), 123.8(\mathrm{CH}), 124.5(\mathrm{C}), 124.6(\mathrm{CH}), 124.8(\mathrm{CH})$, $125.3(\mathrm{CH}), 125.5(\mathrm{C}), 127.8(\mathrm{CH}), 128.0(\mathrm{CH}), 128.2(\mathrm{CH}), 128.2$ (C), $128.7(\mathrm{CH}), 129.8(\mathrm{C}), 130.0(\mathrm{C}), 130.2(\mathrm{CH}), 130.4(\mathrm{C}), 130.6$ (C), 132.4 (C), 3C not seen, $3 \mathrm{CH}$ not seen; HRMS (MALDI, DCTB matrix), $m / z$ : 344.144 (2 ppm) found (calcd for $\mathrm{C}_{26} \mathrm{H}_{18} \mathrm{~N},[\mathrm{M}+\mathrm{H}]^{+}$, requires 344.1434$)$.

16-Chlorophenanthro[9,10-a]acridine (7). It was prepared by adapting a literature procedure. ${ }^{37}$ To 2-(2triphenylenyl)aminobenzoic acid (6;0.36 g, $1.0 \mathrm{mmol}$ ) was added a large excess of $\mathrm{POCl}_{3}(4.0 \mathrm{~mL})$. The solution was stirred at reflux under argon for $72 \mathrm{~h}$ and then concentrated to dryness. The residue was dissolved in $\mathrm{CH}_{2} \mathrm{Cl}_{2}$ and the solution slowly poured onto ice-cooled $15 \%$ aqueous $\mathrm{NH}_{4} \mathrm{OH}$ solution. After decantation, the organic phase was dried over $\mathrm{MgSO}_{4}$, filtered, and concentrated under reduced pressure. Purification by column chromatography on silica gel (eluent: petroleum etherAcOEt 80:20; $\left.R_{f}=0.475\right)$ gave 7 in $84 \%$ yield $(0.31 \mathrm{~g})$ as a yellow solid: IR (ATR): 719, 741, 750, 819, 839, 909, 955, 1016, 1197, $1246,1260,1344,1383,1415,1462,1494,1533,1597,1721$, $2917 \mathrm{~cm}^{-1} ;{ }^{1} \mathrm{H}$ NMR $\left(\mathrm{CDCl}_{3}\right) \delta 7.55(\mathrm{td}, 1 \mathrm{H}, J=7.6$ and $1.0 \mathrm{~Hz})$, 7.64-7.76 (m, 4H), $7.89(\mathrm{td}, 1 \mathrm{H}, J=7.7$ and $1.2 \mathrm{~Hz}), 7.95(\mathrm{~d}, 1 \mathrm{H}, J$ $=8.2 \mathrm{~Hz}), 8.18(\mathrm{~d}, 1 \mathrm{H}, J=9.2 \mathrm{~Hz}), 8.34(\mathrm{~d}, 1 \mathrm{H}, J=8.6 \mathrm{~Hz}), 8.55(\mathrm{~d}$, $1 \mathrm{H}, J=8.7 \mathrm{~Hz}), 8.57-8.60(\mathrm{~m}, 1 \mathrm{H}), 8.68(\mathrm{~d}, 1 \mathrm{H}, J=8.4 \mathrm{~Hz}), 8.72$ $(\mathrm{d}, 1 \mathrm{H}, J=9.2 \mathrm{~Hz}), 8.73-8.76(\mathrm{~m}, 1 \mathrm{H}) ;{ }^{13} \mathrm{C} \mathrm{NMR}\left(\mathrm{CDCl}_{3}\right) \delta 121.4$ (C), $123.3(\mathrm{CH}), 123.4(\mathrm{CH}), 123.9(\mathrm{CH}), 125.0(\mathrm{C}), 125.1(\mathrm{CH})$, $125.7(\mathrm{CH}), 125.7(\mathrm{C}), 126.6(\mathrm{CH}), 126.9(\mathrm{CH}), 127.3(\mathrm{CH}), 127.6$ $(\mathrm{CH}), 127.9(\mathrm{CH}), 128.7(\mathrm{CH}), 128.7(\mathrm{C}), 128.9(\mathrm{C}), 129.3(\mathrm{CH})$, 129.6 (C), 130.0 (C), 130.7 (CH), 131.1 (C), $131.5(\mathrm{CH}), 141.2(\mathrm{C})$, 148.1 (C), 149.9 (C); HRMS (MALDI, DCTB matrix), m/z: 364.089 (1 ppm) found (calcd for $\mathrm{C}_{25} \mathrm{H}_{15} \mathrm{~N}^{35} \mathrm{Cl},[\mathrm{M}+\mathrm{H}]^{+}$, requires 364.0888).

16-Phenoxyphenanthro[9,10- $a]$ acridine (8). It was obtained by adapting a literature procedure. ${ }^{38} \mathrm{~A}$ mixture of 16 chlorophenanthro[9,10- $a$ ]acridine $(7 ; 0.36 \mathrm{~g}, 1.0 \mathrm{mmol})$ and phenol $(0.11 \mathrm{~g}, 1.2 \mathrm{mmol})$ was stirred and heated at $70^{\circ} \mathrm{C}$ before addition of ammonium carbonate $(0.13 \mathrm{~g}, 1.65 \mathrm{mmol})$. The internal temperature was raised to $120{ }^{\circ} \mathrm{C}$ and the reaction mixture was stirred at this temperature for $45 \mathrm{~min}$. It was next cooled to $30{ }^{\circ} \mathrm{C}$ and poured into acetone $(3 \mathrm{~mL})$ cooled at $0{ }^{\circ} \mathrm{C}$. A precipitate took form which was collected and washed with acetone. This solid was treated by sodium hydroxide $(0.26 \mathrm{~g})$ in water $(6 \mathrm{~mL})$, and the mixture extracted by $\mathrm{CH}_{2} \mathrm{Cl}_{2}(3 \times 20 \mathrm{~mL})$. The organic phase was dried over $\mathrm{MgSO}_{4}$, filtered, and concentrated under reduced pressure. Purification by column chromatography on silica gel (eluent: petroleum ether-AcOEt 
80:20; $\left.R_{f}=0.30\right)$ gave 8 in $83 \%$ yield $(0.35 \mathrm{~g})$ as a yellow solid:

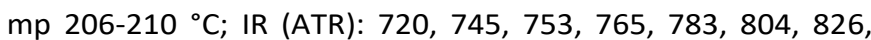
$1019,1069,1106,1163,1211,1250,1300,1347,1363,1396$, $1417,1467,1488,1538,1559,1590,2167,2850,2919,3053 \mathrm{~cm}$ 1; ${ }^{1} \mathrm{H} \mathrm{NMR}\left(\mathrm{CDCl}_{3}\right) \delta 5.83(\mathrm{~d}, 2 \mathrm{H}, J=7.8 \mathrm{~Hz}), 6.48(\mathrm{t}, 1 \mathrm{H}, J=7.3$ $\mathrm{Hz}), 6.61(\mathrm{t}, 2 \mathrm{H}, J=7.8 \mathrm{~Hz}), 7.58-7.67(\mathrm{~m}, 5 \mathrm{H}), 7.90(\mathrm{dd}, 1 \mathrm{H}, J=$ 8.4 and $6.9 \mathrm{~Hz}), 8.24(\mathrm{dq}, 1 \mathrm{H}, J=6.8$ and $3.2 \mathrm{~Hz}), 8.31(\mathrm{~d}, 1 \mathrm{H}, J=$ $9.3 \mathrm{~Hz}), 8.43(\mathrm{t}, 2 \mathrm{H}, J=8.2 \mathrm{~Hz}), 8.48-8.57(\mathrm{~m}, 3 \mathrm{H}), 8.72(\mathrm{~d}, 1 \mathrm{H}, J$ $=9.4 \mathrm{~Hz}) ;{ }^{13} \mathrm{C} \mathrm{NMR}\left(\mathrm{CDCl}_{3}\right) \delta 114.7(\mathrm{C}), 115.1(2 \mathrm{CH}), 121.4(\mathrm{C})$, $122.0(\mathrm{CH}), 122.5(\mathrm{CH}), 123.0(\mathrm{CH}), 123.1(\mathrm{CH}), 123.6(\mathrm{CH}), 125.3$ (C), $125.4(\mathrm{CH}), 126.2(\mathrm{CH}), 126.5(\mathrm{CH}), 126.8(\mathrm{CH}), 127.2(\mathrm{CH})$, $127.3(\mathrm{CH}), 128.2$ (C), 128.6 (C), $128.6(2 \mathrm{CH}), 128.7$ (C), 129.0 $(\mathrm{CH}), 129.1(\mathrm{CH}), 129.7(\mathrm{C}), 130.7(\mathrm{C}), 130.8(\mathrm{CH}), 131.2(\mathrm{CH})$, 149.6 (C), 151.3 (C), 155.6 (C), 156.8 (C); HRMS (MALDI, DCTB matrix), $\mathrm{m} / \mathrm{z}: 422.154\left(0 \mathrm{ppm}\right.$ ) found (calcd for $\mathrm{C}_{31} \mathrm{H}_{20} \mathrm{NO}$, $[\mathrm{M}+\mathrm{H}]^{+}$, requires 422.1539). Crystal data for 8. $\mathrm{C}_{31} \mathrm{H}_{19} \mathrm{NO}, \mathrm{M}=$ 421.47, triclinic, $P-1, a=9.6301(9), b=10.5930(9), c=$ 10.6467(11) $\AA, \alpha=100.520(4), 6=91.593(4), v=95.892(3)^{\circ}, V$ $=1060.99(17) \AA^{3}, Z=2, d=1.319 \mathrm{~g} \mathrm{~cm}^{-3}, \mu=0.079 \mathrm{~mm}^{-1}$. A final refinement on $F^{2}$ with 4864 unique intensities and 298 parameters converged at $\omega R\left(F^{2}\right)=0.1270(R(F)=0.0485)$ for 3977 observed reflections with $I>2 \sigma(I)$. CCDC 2085923.

16-(4-Aminophenoxy)phenanthro[9,10-a]acridine (9). It was prepared by adapting a literature procedure. ${ }^{39} 16-$ Chlorophenanthro[9,10- $a$ ]acridine $(7 ; 0.36 \mathrm{~g}, 1.0 \mathrm{mmol})$ and 4aminophenol $(0.16 \mathrm{~g}, 1.5 \mathrm{mmol})$ were dissolved in dimethylsulfoxide (DMSO; $2 \mathrm{~mL}$ ). Potassium carbonate $(0.28 \mathrm{~g}$, $2.0 \mathrm{mmol}$ ) was next added, and the reaction mixture was stirred at $100{ }^{\circ} \mathrm{C}$ for $5 \mathrm{~h}$. After cooling to room temperature, the reaction was poured onto ice water before extraction with AcOEt $(3 \times 20 \mathrm{~mL})$. The organic phase was washed with brine and dried over $\mathrm{MgSO}_{4}$ before concentration under reduced pressure. Purification by column chromatography on silica gel (eluent: AcOEt-petroleum ether 60:40; $R_{f}=0.575$ ) followed by recrystallization from AcOEt gave 9 in $8 \%$ yield $(35 \mathrm{mg}$ ) as an orange solid: $\mathrm{mp}>26{ }^{\circ} \mathrm{C}$; IR (ATR): $722,755,822,890,956$, $1013,1075,1149,1195,1244,1354,1413,1504,1571,3193 \mathrm{~cm}$ 1; ${ }^{1} \mathrm{H}$ NMR $\left(\mathrm{CDCl}_{3}\right) \delta 3.05\left(\mathrm{~s}, 2 \mathrm{H}, \mathrm{NH}_{2}\right), 5.61(\mathrm{~d}, 2 \mathrm{H}, J=8.5 \mathrm{~Hz})$, $5.93(\mathrm{~d}, 2 \mathrm{H}, J=8.5 \mathrm{~Hz}$ ), $7.61(\mathrm{ddd}, 1 \mathrm{H}, J=7.6,6.7$ and $0.82 \mathrm{~Hz}$ ), 7.63-7.73 $(\mathrm{m}, 4 \mathrm{H}), 7.89$ (ddd, $1 \mathrm{H}, J=7.7,6.7$ and $1.3 \mathrm{~Hz}$ ), 8.23$8.25(\mathrm{~m}, 1 \mathrm{H}), 8.27(\mathrm{~d}, 1 \mathrm{H}, J=9.3 \mathrm{~Hz}), 8.36(\mathrm{~d}, 1 \mathrm{H}, J=8.7 \mathrm{~Hz}), 8.45$ (d, $1 \mathrm{H}, J=8.2 \mathrm{~Hz}), 8.55-8.60(\mathrm{~m}, 2 \mathrm{H}), 8.63-8.66(\mathrm{~m}, 1 \mathrm{H}), 8.75(\mathrm{~d}$, $1 \mathrm{H}, J=9.4 \mathrm{~Hz}) ;{ }^{13} \mathrm{C} \mathrm{NMR}\left(\mathrm{CDCl}_{3}\right) \delta 114.8(\mathrm{C}), 115.4(2 \mathrm{CH}), 116.1$ $(2 \mathrm{CH}), 121.8(\mathrm{C}), 122.6(\mathrm{CH}), 123.3(\mathrm{CH}), 123.3(\mathrm{CH}), 123.7(\mathrm{CH})$, $125.5(\mathrm{CH}), 125.6(\mathrm{C}), 126.1(\mathrm{CH}), 126.4(\mathrm{CH}), 126.8(\mathrm{CH}), 127.3$ $(\mathrm{CH}), 127.4(\mathrm{CH}), 128.2(\mathrm{C}), 128.9(\mathrm{C}), 129.0(\mathrm{CH}), 129.3(\mathrm{CH})$, $129.8(\mathrm{C}), 130.8(\mathrm{CH}), 130.8(\mathrm{C}), 131.4(\mathrm{CH}), 140.8(\mathrm{C}), 149.7(\mathrm{C})$, 150.4 (C), 151.5 (C), 156.6 (C), 1C not seen; HRMS (MALDI, DCTB matrix), $\mathrm{m} / \mathrm{z}$ : $437.168\left(7 \mathrm{ppm}\right.$ ) found (calcd for $\mathrm{C}_{31} \mathrm{H}_{21} \mathrm{~N}_{2} \mathrm{O}$, $[\mathrm{M}+\mathrm{H}]^{+}$, requires 437.1648).

$\mathbf{N}, \mathbf{N}$-Bis(2-triphenylenyl)-2-aminobenzaldehyde (10). It was prepared under an argon atmosphere by adapting a procedure reported previously. ${ }^{30}$ To 2-aminobenzaldehyde $(0.12 \mathrm{~g}, 1.0$ $\mathrm{mmol}$ ) and 2-iodotriphenylene $\mathrm{F}^{50}(0.35 \mathrm{~g}, 2.0 \mathrm{mmol})$ in degassed
$\mathrm{Bu}_{2} \mathrm{O}(1 \mathrm{~mL})$ were successively added activated $\mathrm{Cu}^{51}(13 \mathrm{mg}$, $0.20 \mathrm{mmol})$ and $\mathrm{K}_{2} \mathrm{CO}_{3}(0.43 \mathrm{~g}, 3.0 \mathrm{mmol})$. The mixture was degassed and refluxed under argon for $24 \mathrm{~h}$. During this time, activated $\mathrm{Cu}^{51}(4 \times 13 \mathrm{mg}, 4 \times 0.20 \mathrm{mmol})$ was added after 2, 4, 6 and $8 \mathrm{~h}$ of heating. After cooling to room temperature, the mixture was concentrated. Purification by column chromatography on silica gel (eluent: petroleum ether-AcOEt 90:10; $\left.R_{f}=0.325\right)$ gave 10 in $62 \%$ yield $(0.36 \mathrm{~g})$ as a yellow solid: mp $224^{\circ} \mathrm{C}$; IR (ATR): 718, 750, 816, 857, 872, 943, 1051, 1117, $1156,1191,1236,1265,1306,1346,1384,1435,1475,1503$, $1581,1604,1649,1689,1948,2746,2849,2924,3051,3309 \mathrm{~cm}$ 1; ${ }^{1} \mathrm{H} \mathrm{NMR}\left(\mathrm{CDCl}_{3}\right) \delta 7.39(\mathrm{~d}, 1 \mathrm{H}, J=7.8 \mathrm{~Hz}, \mathrm{H} 3), 7.43(\mathrm{t}, 1 \mathrm{H}, J=$ $7.6 \mathrm{~Hz}, \mathrm{H} 5), 7.48\left(\mathrm{dd}, 2 \mathrm{H}, J=8.8\right.$ and $\left.2.3 \mathrm{~Hz}, \mathrm{H} 3^{\prime}\right), 7.49-7.52(\mathrm{~m}$, $2 \mathrm{H}), 7.60-7.69(\mathrm{~m}, 7 \mathrm{H}, \mathrm{H} 4), 8.04(\mathrm{dd}, 1 \mathrm{H}, J=7.8$ and $1.6 \mathrm{~Hz}, \mathrm{H} 6)$, $8.24\left(\mathrm{~d}, 2 \mathrm{H}, J=8.0 \mathrm{~Hz}\right.$ ), $8.38\left(\mathrm{~d}, 2 \mathrm{H}, J=2.3 \mathrm{~Hz}, \mathrm{H}^{\prime}\right)$ ), 8.55-8.57 $(\mathrm{m}, 2 \mathrm{H}), 8.59\left(\mathrm{~d}, 2 \mathrm{H}, J=9.0 \mathrm{~Hz}, \mathrm{H} 4^{\prime}\right), 8.63-8.64(\mathrm{~m}, 4 \mathrm{H}), 10.42(\mathrm{~s}$, $1 \mathrm{H}, \mathrm{CHO}) ;{ }^{13} \mathrm{C} \mathrm{NMR}\left(\mathrm{CDCl}_{3}\right) \delta 116.8(2 \mathrm{CH}), 123.0(2 \mathrm{CH}), 123.2$ $(2 \mathrm{CH}), 123.4(2 \mathrm{CH}), 123.5(2 \mathrm{CH}), 123.5(2 \mathrm{CH}), 125.3(2 \mathrm{CH}), 125.7$ (2C), $126.2(\mathrm{CH}), 127.0(2 \mathrm{CH}), 127.3(2 \mathrm{CH}), 127.6(2 \mathrm{CH}), 127.7$ $(2 \mathrm{CH}), 129.3(2 \mathrm{C}), 129.4(\mathrm{CH}), 129.5(2 \mathrm{C}), 129.7(2 \mathrm{C}), 129.9(\mathrm{CH})$, 130.4 (2C), 131.4 (2C), 132.2 (C, C2), 135.9 (CH), 148.0 (2C), 150.1 (C, C1), 190.6 (CH, CHO); HRMS (MALDI, DCTB matrix), $\mathrm{m} / \mathrm{z}$ : $573.209(0 \mathrm{ppm})$ found (calcd for $\mathrm{C}_{43} \mathrm{H}_{27} \mathrm{NO}, \mathrm{M}^{+\bullet}$, requires 573.2087).

$\boldsymbol{N}$-(2-Triphenylenyl)phenanthro[9,10-b]-15-acridone (11). It was prepared under an argon atmosphere by adapting a procedure reported previously. ${ }^{43}$ A mixture of 2-(bis(2triphenylenyl))aminobenzaldehyde (10; $0.57 \mathrm{~g}, 1.0 \mathrm{mmol})$, ytterbium triflate $(31 \mathrm{mg}, 50 \mu \mathrm{mol})$ and sodium sulfate $(71 \mathrm{mg}$, $0.50 \mathrm{mmol}$ ) in dimethylformamide (DMF; $5 \mathrm{~mL}$ ) was heated at $100{ }^{\circ} \mathrm{C}$ for $20 \mathrm{~h}$. After cooling to room temperature, diethyl ether $(250 \mathrm{~mL})$ was added, and the organic phase was washed with water $(100 \mathrm{~mL})$. After drying the organic phase over sodium sulfate, the solvent was evaporated under vacuum. Purification by recrystallization from AcOEt gave 11 in $10 \%$ yield (57 mg) as a beige greenish solid: $\mathrm{mp}>260{ }^{\circ} \mathrm{C}$; IR (ATR): 716 , 748, 821, 851, 909, 964, 1033, 1149, 1240, 1303, 1331, 1431, 1470, 1499, 1600, 1642, $3077 \mathrm{~cm}^{-1} ;{ }^{1} \mathrm{H}$ NMR $\left(\mathrm{CDCl}_{3}\right)$ at a lower concentration (about $0.5 \mathrm{mg}$ in $0.5 \mathrm{~mL}$ ) $\delta 6.92(\mathrm{~d}, 1 \mathrm{H}, J=8.6 \mathrm{~Hz}$, $\mathrm{H} 11), 7.30-7.35(\mathrm{~m}, 2 \mathrm{H}), 7.51-7.56(\mathrm{~m}, 2 \mathrm{H}), 7.64,7.70-7.76$ and 7.83-7.85 $(\mathrm{t}, 2 \mathrm{H}, J=7.6 \mathrm{~Hz}, \mathrm{~m}, 2 \mathrm{H}$ and $\mathrm{m}, 2 \mathrm{H}), 7.81(\mathrm{dd}, 1 \mathrm{H}, J=$ 8.6 and $\left.1.8 \mathrm{~Hz}, \mathrm{H}^{\prime}\right), 7.89(\mathrm{~d}, 1 \mathrm{H}, J=8.1 \mathrm{~Hz}), 8.05(\mathrm{~s}, 1 \mathrm{H}), 8.53-$ $8.56(\mathrm{~m}, 2 \mathrm{H}), 8.58(\mathrm{~d}, 1 \mathrm{H}, J=8.4 \mathrm{~Hz}), 8.72(\mathrm{~d}, 1 \mathrm{H}, J=7.9 \mathrm{~Hz}), 8.78$ (d, $1 \mathrm{H}, J=8.4 \mathrm{~Hz}), 8.80-8.82(\mathrm{~m}, 1 \mathrm{H}), 8.84\left(\mathrm{~d}, 1 \mathrm{H}, J=1.8 \mathrm{~Hz}, \mathrm{H} 1^{\prime}\right)$, 8.85-8.87 $(\mathrm{m}, 1 \mathrm{H}), 8.93(\mathrm{~d}, 1 \mathrm{H}, J=8.1 \mathrm{~Hz}), 9.12(\mathrm{~d}, 1 \mathrm{H}, J=8.6 \mathrm{~Hz})$, $9.93(\mathrm{~s}, 1 \mathrm{H}, \mathrm{H} 16) ;{ }^{1} \mathrm{H}$ NMR $\left(\mathrm{CDCl}_{3}\right)$ at a higher concentration (about $1 \mathrm{mg}$ in $0.5 \mathrm{~mL}$ ) $\delta 6.92(\mathrm{~d}, 1 \mathrm{H}, J=8.6 \mathrm{~Hz}, \mathrm{H} 11$ ), 7.30 (d, $1 \mathrm{H}, J=8.3 \mathrm{~Hz}), 7.33(\mathrm{~d}, 1 \mathrm{H}, J=7.4 \mathrm{~Hz}), 7.62-7.65(\mathrm{~m}, 2 \mathrm{H}), 7.69$ $(\mathrm{t}, 1 \mathrm{H}, J=7.8 \mathrm{~Hz}), 7.75(\mathrm{t}, 1 \mathrm{H}, J=7.5 \mathrm{~Hz}), 7.80-7.84(\mathrm{~m}, 3 \mathrm{H}), 7.88$ $(\mathrm{d}, 1 \mathrm{H}, J=8.1 \mathrm{~Hz}), 8.04(\mathrm{~s}, 1 \mathrm{H}), 8.53(\mathrm{dd}, J=7.4$ and $2.8 \mathrm{~Hz}, 2 \mathrm{H})$, $8.58(\mathrm{~d}, 1 \mathrm{H}, J=8.0 \mathrm{~Hz}), 8.71(\mathrm{~d}, 1 \mathrm{H}, J=7.8 \mathrm{~Hz}), 8.77(\mathrm{~d}, 1 \mathrm{H}, J=$ $8.3 \mathrm{~Hz}), 8.80-8.82(\mathrm{~m}, 1 \mathrm{H}), 8.84-8.86(\mathrm{~m}, 2 \mathrm{H}), 8.91(\mathrm{~d}, 1 \mathrm{H}, J=8.1$ $\mathrm{Hz}), 9.12(\mathrm{~d}, 1 \mathrm{H}, J=8.6 \mathrm{~Hz}), 9.91(\mathrm{~s}, 1 \mathrm{H}, \mathrm{H} 16) ;{ }^{13} \mathrm{C} \mathrm{NMR}\left(\mathrm{CDCl}_{3}\right) \delta$ $110.3(\mathrm{CH}), 117.0(\mathrm{CH}), 121.5(\mathrm{C}), 121.7(\mathrm{CH}), 121.7(\mathrm{C}), 123.3$

\section{ACCEPTED MANUSCRIPTं}


(CH), $123.4(\mathrm{CH}), 123.6(\mathrm{CH}), 123.7(\mathrm{CH}), 123.8(\mathrm{CH}), 123.9(\mathrm{CH})$ $124.0(\mathrm{CH}), 124.0(\mathrm{CH}), 124.1(\mathrm{CH}), 124.8(\mathrm{C}), 125.4(\mathrm{CH}), 127.0$ $(\mathrm{CH}), 127.4(\mathrm{CH}), 127.4(\mathrm{CH}), 127.8(\mathrm{CH}), 127.9(\mathrm{CH}), 128.0(\mathrm{CH})$, $128.0(\mathrm{CH}), 128.5(\mathrm{CH}), 128.5(\mathrm{CH}), 128.6(\mathrm{CH}), 128.7(\mathrm{CH}), 128.8$ (C), 129.1 (C), 129.2 (C), 129.3 (C), 130.0 (C), 130.4 (C), 130.6 (C), 130.9 (C), 131.3 (C), 132.7 (C), 133.9 (CH), 134.6 (C), 138.0 (C), 142.1 (C), 144.1 (C), 178.8 (C, C=O); HRMS (ASAP), $m / z$ : $572.2012(0 \mathrm{ppm})$ found (calcd for $\mathrm{C}_{43} \mathrm{H}_{26} \mathrm{NO},[\mathrm{M}+\mathrm{H}]^{+}$, requires 572.2009).

$\mathbf{N}$-Phenyl- $\mathbf{N}$-(2-triphenylenyl)-2-aminobenzaldehyde (12). It was prepared under an argon atmosphere by adapting a procedure reported previously. ${ }^{30}$ To 2-(2triphenylenyl)aminobenzaldehyde $(\mathbf{1} ; 0.35 \mathrm{~g}, 1.0 \mathrm{mmol})$ and iodobenzene $\left(0.24 \mathrm{~g}, 0.13 \mathrm{~mL}, 1.2 \mathrm{mmol}\right.$ ) in degassed $\mathrm{Bu}_{2} \mathrm{O}$ (1 $\mathrm{mL}$ ) were successively added activated $\mathrm{Cu}^{51}(0.20$ equiv, $13 \mathrm{mg}$, $0.20 \mathrm{mmol}$ ) and $\mathrm{K}_{2} \mathrm{CO}_{3}$ ( 2 equiv, $0.29 \mathrm{~g}, 2.0 \mathrm{mmol}$ ). The mixture was degassed and refluxed under argon for $24 \mathrm{~h}$. During this time, activated $\mathrm{Cu}^{51}(4 \times 13 \mathrm{mg}, 4 \times 0.20 \mathrm{mmol})$ was added after 2, 4, 6 and $8 \mathrm{~h}$ of heating. After cooling to room temperature, the mixture was concentrated. Purification by column chromatography on silica gel (eluent: petroleum ether-AcOEt 90:10; $\left.R_{f}=0.21\right)$ gave 12 in $57 \%$ yield $(0.24 \mathrm{~g})$ as a yellow solid:

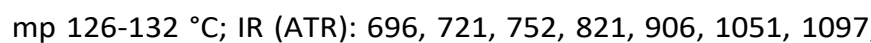
$1155,1191,1241,1265,1305,1348,1390,1436,1453,1476$, 1490, 1592, 1613, 1685, 1947, 2251, 2748, 2849, $3061 \mathrm{~cm}^{-1} ;{ }^{1} \mathrm{H}$ NMR $\left(\mathrm{CDCl}_{3}\right) \delta 7.09(\mathrm{t}, 1 \mathrm{H}, J=7.3 \mathrm{~Hz}), 7.15-7.17(\mathrm{~m}, 2 \mathrm{H}), 7.27-$ $7.37(\mathrm{~m}, 5 \mathrm{H}), 7.54(\mathrm{ddd}, 1 \mathrm{H}, J=8.2,7.5$ and $1.2 \mathrm{~Hz}), 7.59-7.64$ $(\mathrm{m}, 3 \mathrm{H}), 7.98(\mathrm{dd}, 1 \mathrm{H}, J=7.8$ and $1.6 \mathrm{~Hz}), 8.24(\mathrm{~d}, 1 \mathrm{H}, J=8.2 \mathrm{~Hz})$, $8.26\left(\mathrm{~d}, 1 \mathrm{H}, J=2.3 \mathrm{~Hz}, \mathrm{H} 1^{\prime}\right), 8.51-8.53(\mathrm{~m}, 2 \mathrm{H}), 8.61-8.63(\mathrm{~m}, 2 \mathrm{H})$, $10.33(\mathrm{~s}, 1 \mathrm{H}, \mathrm{CHO}) ;{ }^{13} \mathrm{C} N M R\left(\mathrm{CDCl}_{3}\right) \delta 116.4(\mathrm{CH}), 122.8(\mathrm{CH})$, $123.1(\mathrm{CH}), 123.3(2 \mathrm{CH}), 123.4(\mathrm{CH}), 123.45(\mathrm{CH}), 123.45(\mathrm{CH})$, $123.5(\mathrm{CH}), 125.0(\mathrm{CH}), 125.4(\mathrm{C}), 125.9(\mathrm{CH}), 126.8(\mathrm{CH}), 127.2$ $(\mathrm{CH}), 127.5(\mathrm{CH}), 127.6(\mathrm{CH}), 129.3(\mathrm{CH}), 129.3(\mathrm{C}), 129.3(\mathrm{C})$, $129.6(\mathrm{CH}), 129.7$ (C), 129.9 (2CH), 130.3 (C), 131.3 (C), 132.1 (C), 135.7 (CH), 148.0 (C), 148.9 (C), 150.3 (C, C1), 190.8 (CH, CHO); HRMS (MALDI, DCTB matrix), m/z: 423.167 (12 ppm) found (calcd for $\mathrm{C}_{31} \mathrm{H}_{21} \mathrm{NO}, \mathrm{M}^{+\bullet}$, requires 423.1618).

$\boldsymbol{N}$-(2-Triphenylenyl)-9-acridone (13). It was prepared under an argon atmosphere by adapting a procedure reported previously. ${ }^{43}$ A mixture of $\mathrm{N}$-phenyl- $\mathrm{N}$-(2-triphenylenyl)-2aminobenzaldehyde (12;0.44 g, $1.0 \mathrm{mmol})$, ytterbium triflate (31 mg, $50 \mu \mathrm{mol}$ ) and sodium sulfate $(71 \mathrm{mg}, 0.50 \mathrm{mmol}$ ) in DMF $(5 \mathrm{~mL})$ was heated at $100{ }^{\circ} \mathrm{C}$ for $20 \mathrm{~h}$. After cooling to room temperature, diethyl ether $(0.40 \mathrm{~L})$ was added, and the organic phase was washed with water $(100 \mathrm{~mL})$. After drying the organic phase over sodium sulfate, the solvent was evaporated under vacuum. Purification by column chromatography on silica gel (eluent: petroleum ether-AcOEt 80:20; $R_{f}=0.325$ ) gave 13 in $83 \%$ yield $(0.36 \mathrm{~g})$ as a beige solid: $\mathrm{mp}>260{ }^{\circ} \mathrm{C}$; IR (ATR): 722 , $751,801,818,864,912,938,1027,1076,1160,1258,1306$, $1361,1449,1458,1486,1507,1597,1631,2962,3068 \mathrm{~cm}^{-1} ;{ }^{1} \mathrm{H}$ $\operatorname{NMR}\left(\mathrm{CDCl}_{3}\right) \delta 6.89(\mathrm{~d}, 2 \mathrm{H}, J=8.6 \mathrm{~Hz}, \mathrm{H} 4$ and $\mathrm{H} 5), 7.31(\mathrm{t}, 2 \mathrm{H}, J$ $=7.4 \mathrm{~Hz}, \mathrm{H} 2$ and $\mathrm{H} 7), 7.49(\mathrm{t}, 2 \mathrm{H}, J=7.6 \mathrm{~Hz}, \mathrm{H} 3$ and $\mathrm{H} 6), 7.62$ 7.66, 7.73 and 7.77-7.79 $\left(\mathrm{m}, 2 \mathrm{H}, \mathrm{t}, 1 \mathrm{H}, J=7.6 \mathrm{~Hz}\right.$ and $\mathrm{m}, 2 \mathrm{H}$; $\mathrm{H}^{\prime}$,
$H 6^{\prime}, H 7^{\prime}, H 10^{\prime}$ and $\left.H 11^{\prime}\right), 8.52\left(\mathrm{~d}, 1 \mathrm{H}, J=8.1 \mathrm{~Hz}, \mathrm{H} 12^{\prime}\right), 8.65$ (d, $2 \mathrm{H}, J=7.9 \mathrm{~Hz}, \mathrm{H} 1$ and $\mathrm{H} 8), 8.68\left(\mathrm{~s}, 1 \mathrm{H}, \mathrm{H} 1^{\prime}\right), 8.71-8.79(\mathrm{~m}, 3 \mathrm{H})$, $9.00(\mathrm{~d}, 1 \mathrm{H}, J=8.5 \mathrm{~Hz}) ;{ }^{13} \mathrm{C} \mathrm{NMR}\left(\mathrm{CDCl}_{3}\right) \delta 117.1(2 \mathrm{CH}), 121.8$ $(2 \mathrm{CH}), 122.1(\mathrm{C}), 123.7(\mathrm{CH}), 123.7(\mathrm{CH}), 123.8(\mathrm{CH}), 123.8(\mathrm{CH})$, $125.2(\mathrm{CH}), 126.7(\mathrm{CH}), 127.6(2 \mathrm{CH}), 127.8(\mathrm{CH}), 127.9(\mathrm{CH})$, $128.4(\mathrm{CH}), 128.4(\mathrm{CH}), 128.4(\mathrm{CH}), 128.9(\mathrm{C}), 129.1(\mathrm{C}), 130.4$ (C), 130.5 (C), 130.8 (C), 132.4 (C), 133.5 (2CH), 137.9 (C), 143.5 (C), 178.4 (C, C=O); HRMS (ASAP), $m / z: 422.1538$ (0 ppm) found (calcd for $\mathrm{C}_{31} \mathrm{H}_{20} \mathrm{NO},[\mathrm{M}+\mathrm{H}]^{+}$, requires 422.1539 ).

\section{Conflicts of interest}

There are no conflicts to declare.

\section{Acknowledgements}

We thank the Universite de Rennes 1 and the Centre National de la Recherche Scientifique (F. M.). We acknowledge the Fonds Européen de Développement Régional (FEDER; D8 VENTURE Bruker AXS diffractometer). We thank Joshua M. Sims for helpful discussions, H. T. Huynh for providing paracetamol, and F. Lassagne for his help all along the study.

\section{Notes and references}

1 A. Schmidt and M. Liu, Adv. Heterocycl. Chem., 2015, 115 , 287-353.

2 M. Gensicka-Kowalewska, G. Cholewiňski and K. Dzierzbicka, RSC Adv., 2017, 7, 15776-15804.

3 K. Durka, M. Urban, M. Dąbrowski, P. Jankowski, T. Kliś and S. Luliński, ACS Omega, 2019, 4, 2482-2492.

4 M. Wu, W. Wu, X. Gao, X. Lin and Z. Xie, Talanta, 2008, 75 995-1001.

5 J. Kaur and P. Singh, Chem. Commun., 2011, 47, 4472-4474.

6 A.-N. Cho, N. Chakravarthi, K. Kranthiraja, S. S. Reddy, H.-S. Kim, S.-H. Jin and N.-G. Park, J. Mater. Chem. A, 2017, 5, 7603-7611.

7 Y.-y. Jin and Q. Fang, J. Org. Chem., 2019, 84, 3832-3842.

8 R. G. Harvey, Polycyclic Aromatic Hydrocarbons, Wiley-VCH, Weinheim, 2002, pp. 20-31.

9 U. H. F. Bunz, J. U. Engelhart, B. D. Lindner and M. Schaffroth, Angew. Chem., Int. Ed., 2013, 52, 3810-3821.

10 Q. Miao, Polycyclic Arenes and Heteroarenes, Wiley-VCH Verlag GmbH \& Co. KGaA, Weinheim, Germany, 2015.

11 M. Stępień, E. Gońka, M. Żyła and N. Sprutta, Chem. Rev., 2017, 117, 3479-3716.

12 Y. Lin, Z. Liu, Y. Niu, B. Zhang, Q. Lu, S. Wu, G. Centi, S. Perathoner, S. Heumann, L. Yu and D. S. Su, ACS Nano, 2019, 13, 13995-14004.

13 R. M. Acheson, Chemistry of Heterocyclic Compounds: Acridines, John Wiley \& Sons, Wiley-Blackwell, Second Edition, Volume 9, 1973, Chapter 7.

14 T. Do Cao, E. K. Weisburger, P. Mabille and N. P. Buu-Hoï, J. Chem. Soc. C, 1967, 665-668.

15 N. P. Buu-Hoï, M. Dufour and P. Jacquignon, J. Chem. Soc. C, 1969, 1337-1338.

16 Z. Zeng, H. Jin, K. Sekine, M. Rudolph, F. Rominger and A. S. K. Hashmi, Angew. Chem., Int. Ed., 2018, 57, 6935-6939.

17 B. Chakraborty, A. Kar, R. Chanda and U. Jana, J. Org. Chem. 2020, 85, 9281-9289. 
18 S. Zeghada, G. Bentabed-Ababsa, O. Mongin, W. Erb, L. Picot, V. Thiery, T. Roisnel, V. Dorcet and F. Mongin, Tetrahedron, 2020, 76, 131435.

19 N. Mokhtari Brikci-Nigassa, G. Bentabed-Ababsa, W. Erb, F. Chevallier, L. Picot, L. Vitek, A. Fleury, V. Thiéry, M. Souab, T. Robert, S. Ruchaud, S. Bach, T. Roisnel and F. Mongin, Tetrahedron, 2018, 74, 1785-1801.

20 R. L. Vermillion-Salsbury and D. M. Hercules, Rapid Commun. Mass Spectrom., 2002, 16, 1575-1581.

21 Y. Kuninobu, T. Tatsuzaki, T. Matsuki and K. Takai, J. Org. Chem., 2011, 76, 7005-7009.

22 Q. Su, P. Li, M. He, Q. Wu, L. Ye and Y. Mu, Org. Lett., 2014, $16,18-21$.

23 R. S. Begunov, A. A. Sokolov, V. O. Belova and M. E. Solov'ev, Russ. Chem. Bull., 2016, 65, 644-647.

24 K. Fukui, T. Yonezawa, C. Nagata and H. Shingu, J. Chem. Phys., 1954, 22, 1433-1442.

25 Y. Carissan, D. Hagebaum-Reignier, N. Goudard and S. Humbel, J. Phys. Chem. A, 2008, 112, 13256-13262.

26 Y. Shen and C.-F. Chen, Chem. Rev., 2012, 112, 1463-1535.

27 N. Goudard, Y. Carissan, D. Hagebaum-Reignier and S. Humbel, HuLiS 3.3.4, http://ism2.univ-amu.fr/hulis.

28 Y. Kitahara, T. Mizuno and A. Kubo, Tetrahedron, 2004, 60, 4283-4288.

29 E. Berliner, J. Am. Chem. Soc., 1942, 64, 2894-2898.

30 S. Bouarfa, G. Bentabed-Ababsa, W. Erb, L. Picot, V. Thiery, T. Roisnel, V. Dorcet and F. Mongin, Synthesis, 2021, 53, 12711284.

31 T. Fujita, I. Takahashi, M. Hayashi, J. Wang, K. Fuchibe and J. Ichikawa, Eur. J. Org. Chem., 2017, 2017, 262-265.

32 I. V. Borovlev, O. P. Demidov, G. A. Amangasieva and E. K. Avakyan, Tetrahedron Lett., 2016, 57, 3608-3611.

33 P. Huszthy, Z. Kontos, B. Vermes and A. Pinter, Tetrahedron, 2001, 57, 4967-4975.

34 S. Yamada, D. Morizono and K. Yamamoto, Tetrahedron Lett., 1992, 33, 4329-4332.

35 P. Di Fruscia, K.-K. Ho, S. Laohasinnarong, M. Khongkow, S. H. B. Kroll, S. A. Islam, M. J. E. Sternberg, K. Schmidtkunz, M. Jung, E. W. F. Lam and M. J. Fuchter, MedChemComm, 2012, 3, 373-378.
36 D. Hellwinkel and P. Ittemann, Chem. Ber., 1986, 119, 31653197.

37 H. Bertrand, R. Guillot, M.-P. Teulade-Fichou and D. Fichou, Chem. Eur. J., 2013, 19, 14654-14664.

38 A. Albert and B. Ritchie, Org. Synth., 1942, 22, 5-8.

39 S. Figueroa-Perez, S. Bennabi, H. Schirok and M. Thutewohl, Tetrahedron Lett., 2006, 47, 2069-2072.

40 T. L. Su, B. Kohler, T. C. Chou, M. W. Chun and K. A. Watanabe, J. Med. Chem., 1992, 35, 2703-2710.

41 W. Zhou, Y. Yang, Y. Liu and G.-J. Deng, Green Chem., 2013, 15, 76-80.

42 W. Zhou, Y. Liu, Y. Yang and G.-J. Deng, Chem. Commun., 2012, 48, 10678-10680.

43 X.-A. Li, H.-L. Wang and S.-D. Yang, Org. Lett., 2013, 15, 1794 1797.

44 G. Xie, V. Brosius, J. Han, F. Rominger, A. Dreuw, J. Freudenberg and U. H. F. Bunz, Chem. Eur. J., 2020, 26, 160164.

45 M. Napagoda, L. Rulíšek, A. Jančařík, J. Klívar, M. Šámal, I. G. Stará, I. Starý, V. Šolínová, V. Kašička and A. Svatoš, ChemPlusChem, 2013, 78, 937-942.

46 X. Fan and R. C. Beavis, Rapid Commun. Mass Spectrom., $1994,8,199-204$.

47 A. Ingendoh, M. Karas, F. Hillenkamp and U. Giessmann, Int. J. Mass Spectrom. Ion Processes, 1994, 131, 345-354.

48 See for example: R. Liu, G. Zhu and G. Zhang, RSC Adv., 2020, 10, 7092-7098

49 See for example: C.-F. Liu, C. Cheng, Y. Jiang, W.-Y. Lai and W. Huang, New J. Chem., 2017, 41, 13619-13624.

50 R. Nandy and S. Sankararaman, Org. Biomol. Chem., 2010, 8, 2260-2266.

51 A. I. Vogel, A. R. Tatchell, B. S. Furnis, A. J. Hannaford and P. W. G. Smith, Vogel's textbook of practical organic chemistry, 5th edn, Prentice Hall, 1996. 